\title{
WAGES IN A GROWING RUSSIA: WHEN IS A TEN PERCENT RISE IN THE GENDER PAY GAP GOOD NEWS?
}

\author{
Elena Kazakova
}
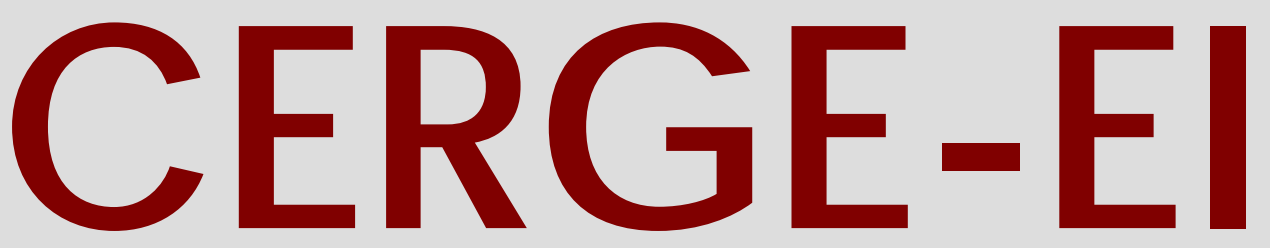

Charles University Centerfor Economic Research and Graduate Education Academy of Sciences of the Czech Republic Ec onomic s Institute 


\title{
Working Paper Series \\ 257 (ISSN 1211-3298)
}

\section{Wages in a Growing Russia: When is a Ten Percent Rise in the Gender Pay Gap Good News?}

\author{
Elena Kazakova
}

CERGE-EI

Prague, May 2005 
ISBN 80-7343-051-7 (Univerzita Karlova v Praze, CERGE)

ISBN 80-7344-040-7 (Národohospodářský ústav AV ČR, Praha) 


\title{
Wages in a growing Russia: \\ When is a ten percent rise in the gender pay gap good news?
}

\author{
Elena Kazakova* \\ CERGE-EI
}

\begin{abstract}
The robust Russian economic recovery after the 1998 financial crisis raised the economic standing of the population, especially for low-paid workers, most of whom are women. In this paper I use the Russian Longitudinal Monitoring Survey from 1996 through 2002 to ask whether this helped to reduce the gender wage gap. The wage measurement has been affected by the wage arrears, an integral feature of the Russian labor market in this period. The raw malefemale wage gap for those not affected by wage arrears exhibits a stable pattern save a 10 percentage point increase in 2000. However, this temporal widening of the gap is due to lowwage women becoming more likely to receive their wages in full than low-wage men in 2000. Furthermore, the wage gap is stable for those who consistently receive full wages.
\end{abstract}

\begin{abstract}
Abstrakt
Rychlé zotavení ruské ekonomiky po finanční krizi v roce 1998 zlepšilo ekonomické postavení populace, zejména málo placených dělníků. $V$ tomto článku se ptám, zda tyto změny pomohly snižit rozdíl mezi platy žen a mužů. Použivám Russian Longitudinal Monitoring Survey pro roky 1996 až 2000. Hrubý rozdíl mezi platy pro ty, kterých se netýkalo prodlení výplaty mezd, se zvýšil mezi lety 1998 a 2000 od 10 procentních bodů. Toto zvětšení mezery Ize nicméně vysvětlit faktem, že nízko placené ženy mají větší šanci na získání mzdy v plné výši než nízko placení muži. Rozdíl mezi těmi, kdo plný plat pravidelně dostávají, je stabilní. Tato zjištění ukazují, že velká část rozdílu v platech mužů a žen v Rusku publikovaná v předchozích studiích je ovlivněná zpožděním výplaty mezd.
\end{abstract}

JEL Classification: J3, J7

Key words: Russia, wages, discrimination, gender.

Acknowledgments: I am grateful to my supervisor, Stepan Jurajda, for his constant support and numerous helpful suggestions. I would also like to thank Randall Filer, Jan Svejnar, Daniel Munich and Libor Dusek for their helpful comments. This research was supported by the U.S. Agency for International Developments SEGIR EP Contract No. PCE-I-00-00-00014-00, reference Russia Task order No. 803 Improvement of Economic Policy Through Think Tank Partnership Project.

*Corresponding author: Center for Economic Research and Graduate Education, Charles University, and Economics Institute, Academy of Sciences of the Czech Republic, Address: Politickych veznu 7, 11121 Prague, Czech Republic, Tel: +420-224-005-222, E-mail address: Elena.Kazakova@cerge-ei.cz 


\section{Introduction}

There has been a lot of research carried out on the relative position of women in early transition from central planning to market economy. These studies typically compare relative wages and employment of men and women before and after the early market reforms. ${ }^{1}$ All the studies that focus on the transition in the East European countries show a narrowing gender wage gap. However, the Russian gap trend is rather obscure: Brainerd (2000) finds an increase in the Russian gap while Reilly (1999) shows that the gap is quite stable over time.

While the latest research available used data from no later than 1998, many radical improvements have happened in the Russian Federation after the 1998 financial crisis. In August 1998, after recording its first positive economic growth Russia was forced to default on its sovereign debt, devalue the ruble, and declare a suspension of payments by commercial banks to foreign creditors. As a result, 1998 ended with a decrease in real output of $4.9 \%$. The collapse of the ruble then caused an increase in exports while imports remained low and there has been a significant economic growth in the Russian economy during the years following the 1998 crisis. In 1999 the Russian economy produced a 5.4\% positive GDP growth rate and this tendency is still sustained: $8.4 \%$ in 2000 and $7.3 \%$ in $2003 .^{2}$

\footnotetext{
${ }^{1}$ See Brainerd (1998), Newel and Reily (1996), Reily (1999), Ogloblin (1999) for Russia, Jones and Ilayperuma (1994) for Bulgaria, Hunt (1997), Krueger and Pischke (1995) for Eastern Germany, Orazem and Vodopivec (1995) for Slovenia, Vecernik (1995 and Flanagan (1998) for Czech Republic, Rutkowski (1996) for Poland.

${ }^{2}$ Source: Russian State Statistic Committee. Most of the recovery was attributed to the import substitution effect after the devaluation; the increase in world prices for Russia's oil, gas and metals; monetary policies; and fiscal policies that led to the first federal budget surplus in 2000 since the formation of the Russian Federation.
} 
This macroeconomic success raised the economic standing of the Russian population. Between 1998 and 2000, real per capita income increased by $22 \%$ and by another $26 \%$ between 2000 and 2002, however, the growth slowed down to $5 \%$ in 2003. The growth rates of total income expenditures for the same periods are $18 \%, 14 \%$ and $6 \%$ respectively. The income growth caused a decline in inequality as the income increases for those in the lowest income quantile were higher than for those with higher incomes. The incomes of the poorest $20 \%$ of the population grew by over $30 \%$ in 2000 and by another $20 \%$ in 2003 . Much of this growth was due to increases of government transfers, especially pension payments, and real wage increases, which made the poverty rates gradually descend to the lowest level in 2003 since before $1995 .^{3}$

Russian labor markets also experienced significant improvements during the after-crisis recovery. ${ }^{4}$ Unemployment fell to $6.3 \%$ in 2003 from its peak value of $10.8 \%$ in November 1998. Only about one in five working age individuals were owed back wages in October 2003, down from almost two out of three in November 1998. The Russian State Committee of Statistics reports an increase in nominal and real monthly average wages over the period of $1998-2002 .^{5}$

Thus, it is important to know if the improvement in the well-being of the society improved the relative position of Russian women on the labor market. One may expect some reduction in the gap coming from the particularly robust growth of wages of the low earners. Women are typically located in the lower part of the

\footnotetext{
${ }^{3}$ Mroz et al. (2004)

${ }^{4}$ The Russian labor market trends are discussed further in Section 3
} 
wage distribution and a compression coming from the bottom of the distribution is therefore likely to raise their average earnings relative to that of men. This argument is consistent with the findings of Brainerd (2000) that the widening wage structure in early Russian transition was the major determinant of the increase in the gender wage gap.

Furthermore, all the existing studies save Gerry et al. (2004) ignore or underestimate the importance of wage arrears in the gender wage gap analysis. However, the wages of about $60 \%$ of Russian workers were affected by arrears in 1996-1998, which caused a sizable shrinkage of the wage sample under analysis and, thus, likely led to the selectivity bias of the results. In addition, the considerable decline of arrears by 2002 could also impact the dynamics of the estimated gap over time via the variation of the full-wage sample.

The absence of research with recent data that also accounts for the wage arrears effect begs further investigation of the changes in economic status of women after the 1998 crisis when incomes began to grow. This paper, therefore, is an attempt to provide evidence on the size and sources of the gender wage gap in Russia during 1996-2002, using the Russian Longitudinal Monitoring Survey (RLMS). In my analysis I will consider the samples for 1996, 1998, 2000 and 2002 separately in order to observe the dynamics of the gender wage gap and its components before, during and after the crisis of 1998. First, I use a standard Blinder-Oaxaca decomposition and then employ various techniques to extract the effect of wage arrears on the gap size.

\footnotetext{
${ }^{5}$ Table 1, Appendix A
} 
The structure of the paper is as follows. The literature on the topic is reviewed in the next section; in part 3 of the paper I proceed with a description of the Russian labor market in 1996-2002. In section 4 I discuss the data and the peculiarities of ready-analysis sample formation. After introducing the estimation procedure in section $5, I$ continue with presenting the results in the subsequent part thematically divided into three parts: the discussion of the Russian labor market trends, assessment of the gender wage gap in dynamics and clearing the wage arrears effect on the gap. Finally, I draw conclusions in section 7.

\section{Literature review}

There is an ample body of literature on labor market gender discrimination ${ }^{6}$ in general, and in transition countries, in particular ${ }^{7}$. In the present literature review I focus on the studies that constitute the literature on the gender wage gap in Russia alone and in a group with other transition economies. First, I review two studies devoted to the gender wage gap in transition and then I proceed with those focused solely on the gap in Russia. The latter studies can be further divided into two groups: one group studies the effect of wage dispersion on the gender earnings differential while the other focuses on occupational segregation as a source of the gap. The last paper reviewed re-examines the Russian gender wage gap taking into account the phenomenon of wage arrears.

\footnotetext{
${ }^{6}$ Orley Ashenfelter and David Card, 1999, Handbook of Labor Economics, Volume 3C ${ }^{7}$ see footnote 1
} 
Newell and Reilly (2000) and Brainerd (2000) examine the pay gap across transition countries employing the same methodology but different data sources. Brainerd uses local stratification data and the main inference is that women experienced greater inequality during the transition period ${ }^{8}$ in Russia and Ukraine while they gained relative to men in the countries of Eastern Europe. She uses the technique of Juhn et al. (1991) that takes into account changes in such components of the residual as the percentile an individual occupies in the residual distribution and the spread of the residual distribution. The author concentrates on the impact of widening wages after the fall of communism on the gender wage gap and finds that women in Russia more than elsewhere suffered from the widening wage structure. This is due to the fact that women's wages constitute the lower part of the wage distribution, which is extremely large in Russia and Ukraine.

In contrast, Newell and Reilly (2000) find that women's relative position on labor markets in transition, including Russia, is rather stable. The authors extend the analysis by Reilly (1999), reviewed below in more details, by considering a number of transition economies.

Reilly also explores the link between the wage gap and rising wage dispersion and focuses his analysis, based on the RLMS, on Russia during the period from 1992 through 1996. His analysis suggests that wage dispersion plays a rather modest role in generating pay differentials by gender. The author estimates gender discrimination with two distinct approaches: the extension of Oaxaca decomposition proposed by Juhn et al. and quantile regression. An interesting

\footnotetext{
${ }^{8}$ Brainerd uses Russian data from 1991 through 1994
} 
insight into the problem is the finding that over the considered period, 1992-1996, the gender wage gap increased mostly for low-wage jobs (by 0.106 log points), while it increased less considerably (by 0.047 ) for higher-wage jobs. However, the magnitude of the gap is largest for the upper percentiles. Exploiting the methodology of Juhn et al., Reilly finds that Russian women benefited from a closure of the gender gap in observable skills and price differentials. Nonetheless, this effect was nearly offset by the increase in the unexplained part of the differential. Interestingly, using the same methodology of Juhn et al. but different data, Brainerd and Reilly receive contradictory results from estimating the trends of the gap as well as the role of wage dispersion on the gap. This contradiction needs to be investigated; however, the issue goes beyond the present paper. Newell and Reilly (2000) replicate Reilly's (1999) analysis for a set of countries in transition including Russia.

Newell and Reilly (1996) study the Russian gender pay differential using data from the first 1992 RLMS round. They estimate the Mincerian wage model and compare it with the estimation of two other extensions of the original model. However, none of the extensions helps to explain the source of the gap. To further explore the impact of occupations on the gap, Newell and Reilly implement the methodology of Brown et al. (1980), which allows them to estimate intraoccupational and inter-occupational wage effects. Their conclusion is that the unexplained part of the gap arises mainly within occupations, while the explained part is small, in both within and across occupations. 
In contrast, Ogloblin (1999), who also studies 1994-1996 RLMS data suggests that the major determinant of the gender pay gap is occupational segregation. A distinctive feature of Ogloblin's methodology is the specification of occupational dummies. He groups four-digit occupations into "male-dominated" and "female-dominated" occupations if more than $70 \%$ of those in occupation are men or women, respectively. The main message of the paper is that occupational segregation by gender explains most of the pay gap. This is a striking result as it reveals almost completely the nature of Russian gender pay differential. Interestingly, the correction for selectivity bias due to wage arrears did not significantly change the results. Referring to the RLMS questionnaires, Ogloblin assumes that women's crowding in the occupations that pay substantially less can be explained by employees' preferences rather than by employers' discrimination. However, the crowding effect can be interpreted also as the existence of barriers to attain certain job positions for women.

I note that all the studies reviewed above use only reported wage data, but wage arrears affect a large part of the Russian labor market: about $38 \%$ of working individuals were owed wages in $1994,54 \%$ in 1996 and up to $64 \%$ in $1998 .{ }^{9}$ As was underlined in the introduction, the issue of the wage arrears effect in the gender wage analysis has been largely overlooked while such an extent of wage arrears is likely to affect the measured gap in the studies reviewed above. The only study that looks at the effect of the arrears on the gender wage gap in Russia is reviewed below. 
Gerry et al. (2004), re-examining the Russian gender wage gap in 19941998 accounting for wage arrears, employ the Blinder-Oaxaca decomposition and control for wage arrears in wage OLS regression. Alternatively, they estimate the gap across sub-groups classified by having or not having wage arrears, payment in-kind and their combinations; their results suggest that wage arrears and payment in-kind attenuate wage discrimination. Using censored regression techniques Gerry et al. also focus on wage discrimination along income distribution and find that the gender wage gap is the highest in the lowest part of income distribution, which is in disaccord with the findings of Reilly (1999). This disaccord underlines the wage arrears importance in wage analysis as it may be explained by the different treatment of arrears in the analyses of Gerry et al. and Reilly.

\section{Russian Labor Market in 1996-2002}

The overview of the Russian labor market, presented below, is based on the data from the Russian Longitudinal Monitoring Survey (RLMS), a dwelling-unitbased survey conducted with the cooperation of leading Russian and American experts. ${ }^{10}$ The goal of the survey is to measure the effect of the reforms' outcomes on the well being of Russian households and individuals. The survey, conducted in two phases that were launched in 1992 and 1996 respectively, supplies an overview of Russian society characteristics from 1992 through 2002.

\footnotetext{
${ }^{9}$ Mroz et al. (2004)

${ }^{10}$ More on the RLMS can be found at http://www.cpc.unc.edu/rIms/
} 
I use the latest RLMS rounds available that correspond to 1996, 1998, 2000 and 2002 respectively. Regarding the economic situation in the country the time periods under my analysis correspond to the years before, during and after the crisis in 1998. The characteristics of the Russian labor market and their time trends are reflected in Table 1. Employment by gender is described for individuals of working age that is of ages $16-55$ for women and $16-60$ for men. ${ }^{11}$

In 2002, the most recent year under analysis, there are about 6 percentage points more women than men among the working-age population while among currently working individuals men outnumber women by over 4 percentage points. Most working individuals of both genders are employed at enterprises, companies, organizations etc.; women are less likely to be self-employed than men. Surprisingly, the gender difference in average years of experience is rather low, about one year, which can be explained by the official younger retirement age of women. ${ }^{12}$ This is supported by the data when the gender differences in experience are viewed across age groups: the difference for the whole working-aged population in the sample is generated mainly in the age group after $45 .{ }^{13}$ The majority of workers who worked during the last 30 days at least 20 hours per week are men, which implies a more regular basis for their labor market activities compared to women. Furthermore, men work on average five hours per week more than women owing to the fact that the share of part-time workers among females is twice that of males. Notwithstanding considerable improvement in the situation of

\footnotetext{
${ }_{11}^{11}$ Working age is determined by the Labor Code of Russian Federation, 2001

${ }^{12}$ Experience is imputed as follows: experience=age-7-years of schooling
} 
wage arrears, from which women benefited substantially more than men, about a fifth of actually working individuals were still owed wages in 2002. The issue of wage arrears is very important for the wage analysis and is discussed in more detail further in the section. Given the above-described trends, the female-male earnings ratio is quite low by international comparison: women earn only $66 \%$ of the average male wage. ${ }^{14}$

The dynamics of labor market characteristics from 1996 through 2002 is as follows. With respect to the gender composition, the share of women in the RLMS data increases from $50 \%$ in 1996 to $53 \%$ in $2002 .{ }^{15}$ The gender difference in the number of individuals currently working fluctuates between 7 and 4 percentage points; however, the adjusted Wald tests indicate that one cannot reject the hypothesis that these gender differences are the same over time. Though most of those currently working are employed in companies, organizations, firms etc., the number of self-employed nearly doubled from 1996 to 1998 , continued to grow through 2000 and stayed stable in 2002.

\footnotetext{
${ }^{13}$ See Appendix A, table 2

${ }^{14}$ See Appendix A, table 3

${ }^{15}$ According to Russian State Statistics Committee (Labor and Employment in Russia, 2003) the share of women among working population was 51\% in 1990 but after 1999 it diminishes and accounts only for 49\% in 2002.
} 
Table 1. Employment by gender in $1998-2002^{\mathrm{a}}$

\begin{tabular}{|c|c|c|c|c|c|c|c|c|c|c|c|c|}
\hline & \multicolumn{3}{|c|}{1996} & \multicolumn{3}{|c|}{1998} & \multicolumn{3}{|c|}{2000} & \multicolumn{3}{|c|}{2002} \\
\hline & Women & Men & $X_{m}-X_{f}^{*}$ & Women & Men & $X_{m}-X_{f}^{*}$ & Women & Men & $X_{m}-X_{f}^{*}$ & Women & Men & $\mathrm{Xm-Xf}$ \\
\hline $\mathrm{N}$ & 2988 & 2926 & -62 & 3136 & 2963 & -173 & 3416 & 3034 & -382 & 3997 & 3526 & -471 \\
\hline Percentage & 50.52 & 49.48 & -1.04 & 51.42 & 48.58 & -2.84 & 52.96 & 47.04 & -5.92 & 53.13 & 46.87 & -6.26 \\
\hline Currently working ${ }^{\mathrm{b}}$ & 62.05 & 68.97 & 6.92 & 59.53 & 64.29 & 4.76 & 60.10 & 67.17 & 7.07 & 61.62 & 65.97 & 4.35 \\
\hline Employees $^{\mathrm{c}}$ & 96.39 & 94.75 & -1.64 & 93.68 & 91.55 & -2.13 & 93.03 & 90.82 & -2.21 & 93.38 & 92.05 & -1.33 \\
\hline Self-employed $^{\mathrm{d}}$ & 3.24 & 4.81 & 1.57 & 6.0 & 8.03 & 2.03 & 6.82 & 9.13 & 2.31 & 6.62 & 7.95 & 1.33 \\
\hline $\begin{array}{l}\text { Average years of } \\
\text { experience }\end{array}$ & 15.46 & 18.21 & 2.75 & 15.44 & 17.61 & 2.17 & 15.58 & 17.02 & 1.44 & 15.51 & 16.58 & 1.07 \\
\hline Actually work ${ }^{\mathrm{f}}$ & 86.32 & 93.00 & 6.68 & 88.34 & 92.61 & 4.27 & 88.06 & 92.75 & 4.69 & 89.30 & 95.56 & 6.26 \\
\hline Weekly hours worked ${ }^{\mathrm{g}}$ & 35.49 & 41.01 & 5.52 & 34.82 & 39.5 & 4.68 & 35.93 & 41.31 & 5.38 & 35.57 & 41.20 & 5.63 \\
\hline Part-time $^{\mathrm{h}}$ & 22.08 & 13.01 & -9.07 & 22.70 & 14.57 & -8.13 & 19.17 & 10.22 & -8.95 & 20.16 & 10.03 & -10.13 \\
\hline Owed back wages $^{\mathrm{g}}$ & 58.77 & 63.38 & 4.61 & 62.89 & 64.89 & 2 & 26.52 & 33.45 & 6.93 & 19.91 & 24.24 & 4.33 \\
\hline Average wages $^{\mathrm{j}, \mathrm{k}}$ & 779,998 & $1,115,086$ & $0.70 * *$ & 871 & 1,213 & $0.72 * *$ & 878 & 1,386 & $0.63 * *$ & 3118 & 4698 & $0.66^{* *}$ \\
\hline
\end{tabular}

${ }^{a}$ Computed from the RLMS data, Rounds VII-IX, over women aged 16-55 and men aged 16-60

${ }^{\mathrm{b}}$ The proportion of individuals in working age who worked at the time of interview

${ }^{c}$ Percentage of currently working individuals that work for a firm, enterprise, company or institution

${ }^{d}$ Percentage of currently working individuals that work but not for a firm, enterprise, company or institution

${ }^{\mathrm{e}}$ Computed for individuals in working age as follows: experience=age - years of schooling -7

f Percentage of currently working individuals that worked in the last month at least 86 hours ( 20 hours per week) prior the interview

${ }^{9}$ Computed for employees who actually worked

${ }^{\mathrm{h}}$ Percentage of employees who actually work and work less than 35 hours per week

Average annual earnings are computed for those working at the time of the interview, including self-employed and those with owed wages

Wages adjusted for monthly regional CPI

${ }^{k}$ In the beginning of 1998 the currency reform took place that replaced old ruble with the new one at 1:1000 rate

${ }^{*} X_{m, f}$ gender-specific means, where the subscripts $m$ and $f$ stand for male and female respectively

$* *$ female-male earnings ratio 
The largest gender difference is found to be in the number of part-time workers: in each round the share of women is about 9 percentage points and in 2002 over 10 percentage points bigger than that of men. The number of individuals working on a part-time basis slightly rises during the crisis, then falls by about 4 percentage points for each gender group in 2000 and stays approximately at the same level in 2002. The pattern of weekly hours worked is rather flat over the period and the gender difference ranges around the five-hour level.

A more thoroughly discussion of wage arrears is needed. Wage arrears have become an integral feature of Russian labor market since 1994: a majority of Russian workers experienced pay disruption in one or another way. ${ }^{16}$ Wage arrears have pervaded all the sectors of the Russian economy but agriculture, industry and state firms in production to a relatively higher degree. ${ }^{17}$

The nature of the phenomenon has been studied in the literature. Lehmann et al. (1999) consider wage arrears as an adjustment instrument of firms to the negative demand shock. They find large regional variation in the incidence of arrears, depending on the industrial structure: workers in Moscow are least affected compared to the workers in agricultural regions and regions with large industrial enterprises. One of the meaningful findings of this study is that the arrears status is determined by enterprises' rather than individual characteristics. Earle and Sabirianova (1999) examine the determinants of wage arrears in Russia and find positive correlation between the probability of delaying wage payments by

\footnotetext{
${ }^{16}$ There are several forms wage arrears can take in Russia: (1) not paid wages, (2) delayed but paid in full wages, (3) paid in time but not in full or (4) paid in part and not in time wages.
} 
a given firm and the existence of other firms in the region that exercise wage arrears. Friebel and Guriev (2000) infer that Russian firms may deliberately attach the workers with the provision of fringe benefits and in-kind payments. The two possible effects of such an attachment policy are the employers' investment into the human capital of the workers without the risk of workers' mobility and the risk of exploitation. Thus, wage arrears are an important characteristic of the labor market in Russian transition and need to be taken into account while analyzing wage differentials.

In 1996 about $60 \%$ of employees of both genders were affected by wage arrears, though women were in a relatively beneficial position. The share of those owed back wages increased during the crisis and, noteworthily, the negative change was significantly bigger for female employees (Table 2).

Table 2. Wage arrears gender differences*

\begin{tabular}{lcccc}
\hline & 1996 & 1998 & 2000 & 2002 \\
\hline Indicator & $\Delta$ & $\Delta$ & $\Delta$ & $\Delta$ \\
\hline Being owed, \%, $\mathrm{X}_{\mathrm{m}}-\mathrm{X}_{\mathrm{f}}$ & 4.61 & 2 & 6.93 & 4.33 \\
Duration in months, $\mathrm{X}_{\mathrm{m}}-\mathrm{X}_{\mathrm{f}}$ & 1.02 & 1.38 & 0.81 & 0.72 \\
Incidence, $\mathrm{X}_{\mathrm{f}} / \mathrm{X}_{\mathrm{m}}{ }^{\diamond}$ & 0.60 & 0.51 & 0.70 & 0.90 \\
\hline
\end{tabular}

- Computed for those who worked during 30 days of the month preceding the interview at least 20 hours per week

However, the situation dramatically improved in 2000 , and further in 2002 , when there were much fewer women experiencing arrears than men. ${ }^{18}$ The

\footnotetext{
${ }^{17}$ Lehmann et al.(1999)

${ }^{18}$ The reduction and following liquidation of wage arrears was a primary task at the start of Putin's presidency. However, at the same time, economic fundamentals improved as well, lowering the pressure on firms to hold back wages.
} 
decrease in the probability to be owed wages appears to be the most significant evolution on the post-crisis Russian labor market and it affects men and women differently. Therefore, any estimation of the relative wages of men and women must take the drop in wage arrears into account.

Finally, the trend of the observed female-male wage gap is as follows. It decreases slightly during the crisis and then rises dramatically in $2000 .{ }^{19}$ Though the female-male earnings ratio grows by a small amount in 2002 , it is still very low by international comparison. ${ }^{20}$ Therefore, one needs to investigate, firstly, why the gap size persists notwithstanding the economic development, and secondly, what causes the fluctuations of its time trend.

\section{Wage sample selection}

In my initial wage analysis I focus on the primary job of the wage-employed who actually worked during the last 30 days before the interview and report positive wages and hours worked. With respect to age I consider working aged individuals: women aged $16-55$ and men $16-60$. To eliminate negligibly small wages and working hours I keep individuals whose wages were at least at the level of the minimum monthly wage rate and who worked at least 86 hours in the month preceding the interview (20 hours per week).

After having eliminated all the observations for which the required information was missing I obtained 1023, 890, 1943 and 2643 individuals in the 
samples for 1996, 1998, 2000 and 2002 respectively. About 54\% of each yearsample are women (in previous studies on Russian gender wage gap the samples were also mainly constituted by women: $52 \%$ in Ogloblin (1999) and $50.2 \%$ in Reilly (1999)). The gender composition of the analysis-ready samples was affected to a certain degree by the elimination process; there are more observations for men than for women dropped from the wage analysis due to incomplete data. ${ }^{21}$

Among others, there are two reasons that lead to the most numerous drops of observations: non-working status and wage arrears. Due to the former reason I do not consider in the analysis around $36 \%$ of working aged individuals. As expected, this group is the youngest and least educated relative to the working individuals. ${ }^{22}$ To correct for this kind of sample selectivity, Heckman's "lambda" approach needs to be undertaken.

Further, I cannot use wage information for those individuals who were owed back wages because the RLMS questionnaire does not allow for distinguishing whether the reported wage is paid in full and net of back payments. As for individual characteristics, the majority of the workers under arrears are males considerably worse educated and on average older than those who were paid in full. Hence, if the currently not working were employed and reliable wage

\footnotetext{
${ }^{19}$ One should account for a small gender difference in the decreasing percentage of nonresponding interviewees.

${ }^{20}$ See Appendix A, Table 3

${ }^{21}$ For instance, about $11 \%$ of working men compared to $7 \%$ of working women did not report their wages. The gender composition of the largest data drops due to non-working status and wage arrears are found on Appendix A, table4.
} 
information for those under arrears was available, I would expect these individuals to constitute the lower part of wage distribution.

Ideally, one would like to employ multi-stage selectivity analysis to correct the results for the two selection choices. To correct the wage analysis for the participation decision is a standard procedure. However, the Russian case is specific due to the phenomenon of wage arrears whose size and gender composition are changing over time. As is noted above, the elimination of observations for the workers with owed wages from the analysis changes the wage distribution of the sample and likely affects the measured gender wage gap. I return to this discussion in Section 6 .

One should also mention another drawback of the data, namely, the fact that the second wave of the survey is based on the dwellings sampled in 1996 . That might possibly affect the income distribution of the sample: more prosperous individuals are moving to new dwellings ${ }^{23}$ and to the metropolitan area while the survey covers the old dwellings whose new inhabitants are likely to be lower earners relative to their predecessors. Thus, on the one hand, I do not observe wages for individuals who are either currently out of work or owed wage payments and expected to be in a lower part of the income distribution whereas, on the other hand, higher earners leave the RLMS sample.

\footnotetext{
${ }^{22}$ The demographic characteristics and educational attainment of the excluded and included individuals from wage analysis are given in Appendix A, tables 3 and 4 respectively.

${ }^{23}$ However, according to Russian State Statistics Committee, the newly constructed dwellings account for about $1 \%$ of the housing stock, which is rather small to cause a serious problem to the sample representativeness.
} 


\section{Estimation procedure}

Most of the studies on labor market discrimination adopt the Blinder-Oaxaca decomposition as a methodology to estimate wage discrimination-related differentials. ${ }^{24}$ The approach allows the gap to be splitting into two parts: the first part explains the gap via the differences in productivity characteristics while the differences in estimated coefficients give rise to the second part of the gap, which is often referred to as an indicator of discrimination. This method relies on the estimation of separate wage equations for each gender and the fact that least squares regressions pass through the sample means:

$$
\overline{\ln w_{j}}=\hat{\beta}_{j}^{\prime} \bar{X}_{j}, j \in\{m, f\}
$$

where $\overline{\ln w_{j}}$ are the gender-specific means of the natural logarithm of wages, $\bar{X}_{j}$ are vectors of mean values of individual characteristics, $\hat{\beta}_{j}^{\prime}$ are the corresponding estimated coefficients and, finally, $m$ and $f$ denote male and female respectively. The general form of the decomposition is as follows:

$$
\overline{\ln w_{m}}-\overline{\ln w_{f}}=\left({\overline{X_{m}}}^{\prime}-{\overline{X_{f}}}^{\prime}\right) \tilde{\beta}+{\overline{X_{m}}}^{\prime}\left(\hat{\beta}_{m}-\tilde{\beta}\right)+{\overline{X_{f}}}^{\prime}\left(\tilde{\beta}-\hat{\beta}_{f}\right)
$$

\footnotetext{
${ }^{24}$ One should acknowledge that Blinder-Oaxaca methodology relies on a correct specification of the model, which is fairly questionable in the Russian case though widely used in the previous studies on the Russian gender wage gap.
} 
The first term on the right-hand side is the part of the gross differential that arises due to the gender differences in productivity characteristics, where $\tilde{\beta}$ are the returns under non-discriminatory wage structure. The second and the third terms reflect the deviation of the wage setting from the non-discriminatory one. The estimation procedure is greatly determined by the choice of the unobservable $\tilde{\beta}$. There are several ways to simulate the non-discriminatory wage structure discussed in the literature on discrimination in the labor market. In my analysis I follow Oaxaca and Ransom (1994) who suggest using the coefficients from the estimation of the pooled data-set.

To estimate the gender wage differential for the four separate year samples I regress the logarithm of wages ${ }^{25}$ on three sets of variables that correspond to the following models. The first model represents the basic Mincerian equation, the second is extended with occupational dummy variables and the third model is further augmented with regional controls. Detailed description of the models is presented below, in Table 3.

\footnotetext{
${ }^{25}$ As a measure of earnings I use the logarithm of monthly wages, adjusted for regional CPI, time trends, hours worked and part/full-time status by estimating the following regression equation:

$\ln w_{i}=a T_{i}^{\prime}+a_{p} P+a_{p h} P \ln h+a_{f h} F \ln h$,

where $T_{i}^{\prime}$ is the vector of time dummy variables that relate to the reference month, $P$ is a dummy variable for part-time status, PInh and FInh are the interections of part-time and full-time status with the logarithm of hours worked in the month preceding the interview, and finally, $a, a_{p}, a_{p h}, a_{f h}$ are the corresponding coefficients.
} 


\section{Table 3. Regression models}

Experience $^{a}$

Experience squared ${ }^{b}$

Educational dummies ${ }^{c}$

University

Specialized secondary

Vocational school with general secondary degree

Vocational school without general secondary degree

Incomplete secondary

Omitted category: general secondary as the only education

degree $^{\mathrm{d}}$

Model 2. Extended with occupational controls
$=$ Model 1 plus

Occupational dummies
Professionals

Technicians

Clerks

Service employees

Craft and plant workers Omitted category: army

Model 3. Extended with occupational and regional dummies
$=$ Model 2 plus

Regional dummy variables for 31 Russian regions ${ }^{e}$ Dummy variable for rural residency Omitted category: Moscow oblast ${ }^{\dagger}$

a experience $=$ age - years of schooling -7

${ }^{b}$ experience squared $=$ experience ${ }^{\wedge} 2 / 100$

"Schooling in Russia is compulsory through "incomplete secondary" education, that is roughly equivalent to junior high school in the US, general secondary is another two years of schooling. Vocational school takes three years with "incomplete secondary" and two years with general secondary degrees. Specialized secondary schools are similar to junior colleges in the US. Average education attainment in the sample under analysis by gender is presented in Table 6, Appendix A.

${ }^{\mathrm{d}}$ About $90 \%$ of workers in the sample have general secondary education.

'These are 32 out of 89 Russia's regions covered by the RLMS

${ }^{f}$ Gross regional product of Moscow oblast is the closest to the average level across the regions according to Goskomstat Yearbook "Russian Regions", 2002 


\section{Results}

\subsection{Russian labor market trends in 1996-2002}

Regarding the Russian labor market trends, one can see noteworthy changes in the returns to productivity characteristics: human capital characteristics become more important determinants of earnings. The returns to experience and schooling gain more significance, both economic and statistical, over time. In Table 4 below I present the returns to human capital characteristics estimated by the basic Mincerian wage model; all other estimated coefficients from the regression analysis for each of the samples are in Appendix B.

The effect of experience on earnings changes remarkably over time. In 1996, before the crisis, the estimates of experience are statistically insignificant. During the crisis the significance of the returns to experience rises in both economic and statistical terms. Finally, in 2000 all the coefficients of experience

grow statistically significant at $1 \%$ level. Note that after the positive economic changes brought by the after-crisis recovery the returns to experience became higher for men than for women: the gender differences in returns to experience in 2000 are $0.013,0.006$, and 0.001 log points in models 1,2 , and 3 respectively. However, in 2002 returns to women's experience drop drastically and lose statistical significance in the first two models. 
Table 4. Returns to human capital characteristics in 1996-2002

\begin{tabular}{|c|c|c|c|c|c|c|c|c|c|c|c|c|}
\hline & \multicolumn{3}{|c|}{1996} & \multicolumn{3}{|c|}{1998} & \multicolumn{3}{|c|}{2000} & \multicolumn{3}{|c|}{2002} \\
\hline & Pooled & Female & Male & Pooled & Female & Male & Pooled & Female & Male & Pooled & Female & Male \\
\hline $\mathrm{N}$ & 1023 & 550 & 473 & 890 & 475 & 415 & 1943 & 1051 & 892 & 2643 & 1395 & 1248 \\
\hline R-squared & 0.043 & 0.066 & 0.053 & 0.038 & 0.075 & 0.041 & 0.059 & 0.092 & 0.071 & 0.071 & 0.099 & 0.082 \\
\hline $\begin{array}{l}\text { Experience } \\
\text { Experience }\end{array}$ & 0.001 & 0.015 & 0.000 & $0.017^{* *}$ & $0.050^{* * *}$ & 0.003 & $0.034^{* * *}$ & $0.034^{* * *}$ & $\begin{array}{l}0.047^{* * *} \\
-\end{array}$ & $0.014^{* * *}$ & 0.008 & $0.021^{* * *}$ \\
\hline squared & -0.017 & -0.053 & -0.015 & $-0.043^{* *}$ & $-0.130^{\star * *}$ & -0.013 & $-0.079^{\star \star *}$ & $-0.080^{* * *}$ & $0.108^{* * *}$ & $-0.031^{* * *}$ & -0.015 & $-0.049^{* * *}$ \\
\hline $\begin{array}{l}\text { University } \\
\text { Specialized }\end{array}$ & $0.277^{\star * *}$ & $0.255^{\star \star \star}$ & $0.327^{* * *}$ & $0.355^{\star * *}$ & $0.423^{* * *}$ & $0.320^{\star \star *}$ & $0.435^{\star \star \star}$ & $0.589^{\star \star \star}$ & $0.340^{\star \star *}$ & $0.499^{\star \star \star}$ & $0.555^{\star * *}$ & $0.522^{\star \star *}$ \\
\hline $\begin{array}{l}\text { secondary } \\
\text { Vocational } \\
\text { with }\end{array}$ & 0.101 & 0.106 & $0.263^{* *}$ & $0.144^{*}$ & $0.213^{* *}$ & $0.282^{\star *}$ & 0.052 & $0.173^{* *}$ & $0.180^{* *}$ & $0.128^{* * *}$ & $0.199^{\star * *}$ & $0.232^{\star * *}$ \\
\hline $\begin{array}{l}\text { secondary } \\
\text { Vocational } \\
\text { w/o }\end{array}$ & -0.065 & -0.115 & -0.023 & 0.074 & 0.018 & 0.079 & $0.162^{\star *}$ & $0.218^{* *}$ & 0.050 & $0.106^{* * *}$ & $0.106^{*}$ & 0.083 \\
\hline $\begin{array}{l}\text { secondary } \\
\text { Incomplete }\end{array}$ & 0.042 & $\begin{array}{l}-0.098 \\
-\end{array}$ & 0.121 & $0.171^{*}$ & 0.191 & 0.070 & 0.039 & 0.074 & -0.034 & 0.090 & 0.074 & 0.074 \\
\hline secondary & $-0.196^{* *}$ & $0.311^{* * *}$ & -0.179 & -0.053 & -0.079 & -0.101 & -0.019 & -0.051 & -0.063 & -0.023 & $-0.121^{* *}$ & -0.023 \\
\hline
\end{tabular}

*statistically significant at $10 \%$ level, ** at $5 \%$ level, and *** at $1 \%$ level 
Among education degrees university, as expected, brings the highest returns. Furthermore, the returns to university are growing considerably over time and higher for women in all the models across all the year-samples save in 1996, model 1 and in 2002 the returns are roughly equally high for both genders. By 2000 the coefficients of university dummy variable grew statistically significant at $1 \%$ level in all regressions across all the three models. Interestingly, the women's returns to university have grown by about 23 log percentage points only for four years while the growth rates of the corresponding returns of men are fairly modest. However, in 2002 returns to university degree stay high for both genders. Thus, if one believes that the gender gap is due to the differences in returns to the individual endowments then one may anticipate a closure of the gender gap due to this substantial increase in the returns to women's human capital characteristics.

These results are of no surprise. The combination of poor economic conditions and an excessive supply of well-educated labor force in the beginning of transition ranked the returns to education in Russia among the lowest in the world (Benitez-Silva, 2000). However, the comparison of the returns to education in precrisis and after crisis years suggests that once the economy began developing more dynamically educational attainment became an important determinant of earnings. This is in accord with Brainerd's (1998) predictions that during the transition the returns to education in Russia should increase as a reaction of the labor supply to the wage dispersion growth by acquiring the skills in demand. Similar logic is applied to the returns to experience. In early years of transition the experience gained from working in the central-planned economy did not have a 
high value; however, the experience gained during transition is appreciated much more.

\subsection{The gender wage differential}

The dynamics of the raw gender wage gap versus the estimated coefficients of the female dummy variable for each of the three models is presented in the first row of Table $5{ }^{26}$ There are two things that need to be noted. The first is a sizable increase of the gap in 2000 along a rather otherwise flat trend. ${ }^{27}$ However, the rise in the gender wage gap can be good news as it might be explained by the diminishing wage arrears. In 2000 many more women than men were paid their wages in full relative to 1998 . The women not paid their wages in 1998 enter the wage sample in 2000 and this might have raised the size of the gap as low-paid workers were more likely to be affected by arrears. More thorough analysis of the wage arrears effect on the gap follows in the next subsection. The second observation is that the explanatory power of occupations and regions is changing considerably over time. In 1996, 1998 and 2002 occupational and regional controls explain very little; however, in 2000 these variables reduce the unexplained gap by $12 \log$ points (-(raw1 - raw3)).

\footnotetext{
${ }^{26}$ The raw gap is defined as $\left(\overline{\ln w_{f}}-\overline{\ln w_{m}}\right)$

${ }^{27}$ To estimate the significance of the change in the raw gender wage gap I, in addition, estimated a regression equation for the pooled data-set of 1998 and 2000-year samples that includes interaction of the gender and productivity variables belonging to the 2000 sample. The coefficient of the female dummy variable of 2000 is equal to 0.106 and significant at $10 \%$ level.
} 
Table 5. The raw gap versus the estimated coefficients of female dummy

\begin{tabular}{|c|c|c|c|c|}
\hline Models & $\begin{array}{c}\text { variable } \\
1996 \\
\end{array}$ & 1998 & 2000 & 2002 \\
\hline 0 . Raw gender wage gap & -0.27 & -0.32 & -0.41 & -0.32 \\
\hline 1.Basic & -0.33 & -0.38 & -0.47 & -0.37 \\
\hline $\begin{array}{l}\text { 2. Augmented with occupational } \\
\text { dummies }\end{array}$ & -0.30 & -0.37 & -0.39 & -0.36 \\
\hline $\begin{array}{l}\text { 3. Augmented with occupational and } \\
\text { regional dummies }\end{array}$ & -0.30 & -0.33 & -0.35 & -0.35 \\
\hline
\end{tabular}

-All estimates are statistically significant at $1 \%$ level

The results from the decomposition of the basic and extended models in Table 6 suggest that human capital characteristics hardly explain anything of the gap as well as in the previous literature on Russian gender wage gap. On the contrary, if wages were set solely according to human capital characteristics and women's observed productivity characteristics were at the men's level the gross wage differential would be $4.2,3.3,3.2$ and 3.2 log percentage points bigger in 1996, 1998, 2000 and 2002 respectively.

The extension of the basic Mincerian model with occupational dummies gives evidence that occupations do shed light on the source of the gender wage differential and they alone explain $39 \%, 26 \%, 44 \%$ and $24 \%$ of the gross differential for the samples of 1996, 1998, 2000 and 2002 respectively. Together with regional controls in the third model occupations explain $64 \%, 35 \%, 53 \%$ and $28 \%$ of the gross gap. 
Table 6. Gender wage gap decomposition

\begin{tabular}{|c|c|c|c|c|c|}
\hline & & 1996 & 1998 & 2000 & 2002 \\
\hline \multicolumn{6}{|l|}{ Models } \\
\hline & Gross differential & 0.272 & 0.319 & 0.409 & 0.321 \\
\hline \multirow{4}{*}{ 1.Basic } & Explained part & -0.042 & -0.033 & -0.032 & -0.032 \\
\hline & Experience & -0.004 & -0.013 & -0.022 & -0.002 \\
\hline & Education & -0.037 & -0.019 & -0.010 & -0.030 \\
\hline & Unexplained part & 0.313 & 0.352 & 0.439 & 0.354 \\
\hline \multirow{5}{*}{$\begin{array}{l}\text { 2. Augmented with occupational } \\
\text { dummies }\end{array}$} & Explained part & 0.060 & 0.047 & 0.135 & 0.044 \\
\hline & Experience & -0.005 & -0.014 & -0.022 & -0.002 \\
\hline & Education & -0.042 & -0.022 & -0.024 & -0.030 \\
\hline & Occupations & 0.107 & 0.083 & 0.180 & 0.076 \\
\hline & Unexplained part & 0.211 & 0.272 & 0.274 & 0.277 \\
\hline \multirow{6}{*}{ 3. Augmented with occupational } & Explained part & 0.065 & 0.081 & 0.165 & 0.061 \\
\hline & Experience & -0.009 & -0.019 & -0.021 & -0.003 \\
\hline & Education & -0.034 & -0.011 & -0.029 & -0.027 \\
\hline & Occupations & 0.165 & 0.086 & 0.180 & 0.094 \\
\hline & Regions & 0.008 & 0.024 & 0.035 & -0.003 \\
\hline & Unexplained part & 0.207 & 0.239 & 0.244 & 0.261 \\
\hline
\end{tabular}

One can notice that the explanatory power of the occupational and regional dummies grows considerably in 2000 while it stays rather low in all the other years under analysis. Macroeconomic parameters for 2000 reflect the stable economic growth, which continues in 2002 as well. A probable explanation is a delayed effect of the 1998 crisis. The crisis caused a lot of variation in wage determination across occupations and regions in 2000 that was imaged in the corresponding returns. However, the returns to occupations and regions in 2002 come back to the level of 
1998. Thus, one can argue that the wage structure in Russia does not change notwithstanding the recent economic development trends.

\subsection{Wage arrears and gender wage gap}

As was underlined earlier, wage arrears exhibit the most volatile pattern among Russian labor market trends in 1996-2002: the share of workers owed wages diminishes from about $60 \%$ in 1996 to less than $25 \%$ in 2002 and the gender composition of the subsample affected by arrears changes over time as well. Furthermore, the absence of the reliable wage information for individuals under arrears leads to a sizable shrinkage of the sample under analysis. Thus, not observing up to $60 \%$ of the employed possibly affects the gender wage gap estimation.

Therefore, it is particularly important to investigate more thoroughly wage arrears in the context of gender wage gap analysis and their possible effects on the gap estimation. Being concentrated in the lowest part of the distribution, women are more likely to be owed wages. However, the arrears descriptive statistics presented in Table 7 suggest that the relative position of women with respect to wage arrears is rather favorable. There are always fewer women under arrears relative to men; they are owed on average less and for a shorter period of time. Note that in 2002 all the gender differences with respect to the wage arrears considerably decrease together with the reduction of the wage arrears expanse.

Thus, the question arises whether the wage arrears are gender neutral or do favor women. To answer this question I estimate how gender determines such parameters of wage arrears as amount owed, duration and probability of being 
owed. First, I use mean comparison to estimate the effect of gender on the logarithm of amount owed per month, duration and probability of being owed and then I extend the right-hand side of the equation with the full set of variables, including productivity characteristics with tenure among others, occupational and regional controls. The estimated female dummy variable coefficients in the corresponding regression equations are presented in Table 8.

The estimates of the mean comparison confirm that women are expected to be owed a smaller amount and this effect grows gradually from -0.38 log points in 1996 to -0.42 in 2000 and then decreases to -0.30 in 2002 . This pattern persists in the full model as well. In fact, women can be owed a smaller amount relative to men due to the lower average wages of women. If this were the case, then the amount owed gap in the full model would be equal to the estimated wage gap after controlling for differences in productivity characteristics, occupations and regions. However, the former is always larger, which implies that there is still room for positive discrimination of women. One should, though, acknowledge that the wage and arrears samples are qualitatively different: the wage sample is composed of relatively higher earners, who, according to Reilly (1999), have a greater gender wage gap. 
Table 7. Descriptive statistics of wage arrears

\begin{tabular}{lccccccccccccc}
\hline & & 1996 & & \multicolumn{1}{c}{1998} & \multicolumn{2}{c}{2000} & \multicolumn{1}{c}{2002} \\
\hline Indicator & Female & Male & $\Delta$ & Female & Male & $\Delta$ & Female & Male & $\Delta$ & Female & Male & $\Delta$ \\
\hline Being owed, \% & 58.77 & 63.38 & 4.61 & 62.89 & 64.89 & 2 & 26.52 & 33.45 & 6.93 & 19.91 & 24.24 & 4.33 \\
Duration, months & 2.95 & 3.97 & 1.02 & 4.70 & 6.08 & 1.38 & 4.48 & 5.30 & 0.81 & 3.21 & 3.92 & 0.72 \\
Incidence & 1252 & 2092 & 0.60 & 1969 & 3879 & 0.51 & 2886 & 4094 & 0.70 & 4592 & 5118 & 0.90 \\
\hline
\end{tabular}

$\Delta$ Stands for gender difference, in case of the incidence computed as $X_{f} / X_{m}$ and as $X_{m}-X_{f}$ otherwise

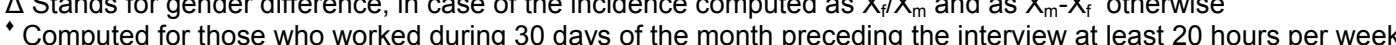

${ }^{\circ}$ The amount owed is expressed in thousand rubles for 1996 owing to the monetary reform in 1998 that scaled rubles at the rate 1:1000

Table 8. The explanatory power of gender in incidence, duration and probability of being owed equations

\begin{tabular}{|c|c|c|c|c|c|c|c|c|}
\hline & \multicolumn{2}{|c|}{1996} & \multicolumn{2}{|c|}{1998} & \multicolumn{2}{|c|}{2000} & \multicolumn{2}{|c|}{2002} \\
\hline Dependant variable & d_female & St.error & d_female & St. error & d_female & St. error & d_female & St.error \\
\hline \multicolumn{9}{|c|}{ Parsimonious specification } \\
\hline Amount owed & $-0.383 * * *$ & 0.041 & $-0.407 * * *$ & 0.039 & $-0.421 * * *$ & 0.066 & $-0.307 * * *$ & 0.092 \\
\hline Duration & $-1.021 * * *$ & 0.163 & $-1.385^{* * *}$ & 0.356 & -0.815 & 0.543 & -0.198 & 0.701 \\
\hline Probability of being owed & $-0.113 * * *$ & 0.042 & -0.051 & 0.044 & $-0.227 * * *$ & 0.044 & -0.072 & 0.056 \\
\hline \multicolumn{9}{|c|}{ Full model } \\
\hline Amount owed & $-0.390 * * *$ & 0.044 & $-0.435 * * *$ & 0.040 & $-0.456 * * *$ & 0.074 & $-0.300 * * *$ & 0.108 \\
\hline Duration & $-0.690 * * *$ & 0.165 & $-0.851 * *$ & 0.346 & -0.463 & 0.598 & -1.103 & 1.014 \\
\hline Probability of being owed & 0.007 & 0.054 & -0.005 & 0.055 & $-0.137 * *$ & 0.056 & -0.034 & 0.068 \\
\hline
\end{tabular}

${ }^{*},{ }^{* *},{ }^{* * *}$ correspond to $10 \%, 5 \%$ and $1 \%$ significance levels.

The full model includes on the right-hand side female dummy variable, experience, tenure, educational, occupational and regional 
In 1996 and 1998 there is also strong support in the evidence that wages of women are delayed for a shorter time though the estimated coefficient of gender variable is not statistically significant in 2000 and 2002. Furthermore, the probability of being owed seems not to vary by gender in 1998 and 2002 but is lower for women in 1996 and, particularly, in 2000.

After adding other explanatory variables, in the incidence equation the estimated coefficient of female dummy variable does not change much whereas in the duration equation the negative effect of gender decreases in all years. This means that other variables such as human capital characteristics and occupational and regional controls have a bigger impact on the arrears' duration compared to the incidence, where the gender variable on its own explains roughly as much as with the other variables together.

The loss of statistical as well as economic significance of the gender variable in the Probit equation after controlling for productivity characteristics, occupations and regions, means that the probability of being owed heavily depends on the parameters other than gender as one of the individual characteristics, which is in line with the findings of Lehmann et al. (1999) who finds more wage arrears variation across regions and industries. Thus, women are less affected by wage arrears not because of more favorable treatment but due to the fact that they are employed in occupations and regions less pervaded by wage arrears and they are owed a smaller amount mainly because their wages are smaller than those of men. 
The estimates of the gender wage gap presented in the previous subsection should be taken with a certain degree of precaution. As was underlined earlier, the analysis-ready sample is subject to different kinds of selection and the multi-stage selectivity correction needs to be applied. Such a correction would ideally include the standard Heckman's lambda technique to correct for the self-selection into labor force decision and for the sample selection due to wage arrears. However, the results of selectivity correction for participation decision are shown to be statistically insignificant, which was also the case in previous studies. ${ }^{28}$ In the framework of the present analysis I make an attempt to get a deeper insight into the effect of wage arrears on the size of the gap in order to see if the wage arrears are a cause of the increase in the gender wage gap in 2000.

To employ Heckman's lambda to correct for sample selection due to wage arrears, one needs instrumental variables correlated with wage arrears but uncorrelated with the wages themselves. Such instrumental variables are hard to find, therefore, I introduce alternative procedures to extract the effect of the changes in wage arrears on the gap and thus obtain more evidence on the actual evolution of its size.

The most straightforward way to estimate the gap net of the wage arrears effect would be to estimate it for the subsample of those who were always paid in full using panel data. However, such a subsample is negligibly small due to the turnover in the sample under arrears itself: too few workers were never owed wages during the six year period. Another way to estimate the gap among

\footnotetext{
${ }^{28}$ See Gerry, Christopher J. et al. (2004)
} 
individuals not affected by wage arrears is to observe the changes in the gap for those who keep the same wage status in two subsequent periods. I select workers who were paid wages in full in each pair of periods, 1996 and 1998, 1998 and 2000 , and 2000 and 2002. The results of panel data analysis are presented in Table 9.

Table 9. Time differences in the gender wage gap estimated for those

\begin{tabular}{lccc}
\hline & \multicolumn{3}{c}{ who were paid wages in full in two subsequent periods } \\
\cline { 2 - 4 } Models & $\Delta 1996 / 1998$ & $\Delta 2000 / 1998$ & $\Delta 2002 / 2000$ \\
\hline $\begin{array}{l}\text { Number of observations in each of } \\
\text { the years }\end{array}$ & 313 & 435 & 931 \\
\hline & 0.09 & 0.01 & 0.08 \\
1.Basic & $(0.13)$ & $(0.10)$ & $(0.07)$ \\
& 0.11 & 0.04 & 0.03 \\
2. Augmented with occupational & $(0.15)$ & $(0.11)$ & $(0.07)$ \\
dummies & & & \\
& 0.10 & 0.03 & 0.05 \\
3. Augmented with occupational & & & \\
and regional dummies & $(0.13)$ & $(0.10)$ & $(0.07)$ \\
\hline
\end{tabular}

$\Delta$ is a time difference between given years

The standard errors are given in parenthesis, all time changes are statistically insignificant

The pattern of the changes in the gap in the panel analysis shows that the relative position of women is rather stable if not improving over time: the time changes in the gap among those who were paid wages in full in two subsequent periods are positive but not statistically significant. This evidence points out the confusion that can emerge if one relies on the results offered by cross-sectional analysis. To contrast further the dynamics of the gap from basic Mincerian equation estimated by cross-sectional and panel data I present the corresponding trends in figure 1. 


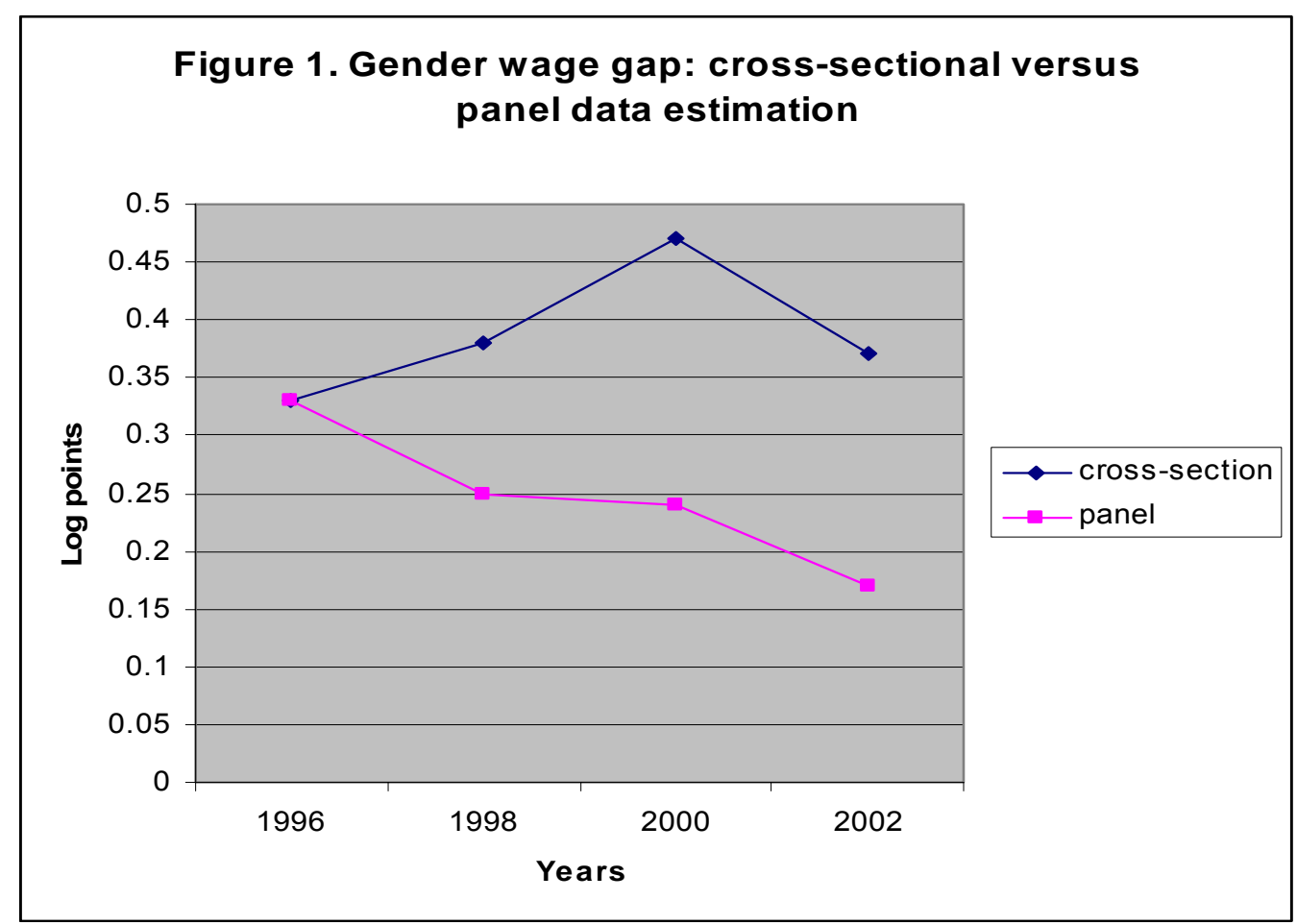

The trends presented above stress the difference between the results from estimating the gap for the sample that was subject to constant inflows from the arrears sample and the gap evolution by pair of periods for the subsamples net of such inflows. Therefore, the fluctuations in the wage gap over the years were caused mainly by the entering of the formerly owed wages into the wage sample.

To argue that the evolution of wage arrears is a reason of the gap size fluctuations one would like to see and compare the characteristics by gender of newcomers into the wage analysis from the sample under arrears in 2000 and $2002 .{ }^{29}$ The relative human capital characteristics of women who come back to the analysis in 2002 are much more beneficial than in 2000 . For instance, the negative gender difference in the share of university degree holders doubles in 2002, from - 
4.4 to -8.2 percentage points, while the positive gender difference in the number of individuals without secondary education grows by one percentage point. Regarding occupational composition of the newcomers, the reduction of the gender difference in the share of unskilled workers is more than twice the size in 2000 than in 2002, which also supports the hypothesis that the fluctuations in the gender wage gap trend might be caused by a greater share of women among low-wage newcomers in the wage sample in 2000 than in 2002.

Further, I consider the proportion of the newcomers for each gender by wage distribution quartiles. Noteworthily, the share of the movers among women in the lowest wage distribution quartile diminishes by over 11 percentage points from $26 \%$ in 2000 to $14 \%$ in 2002 while the corresponding share of men stays nearly the same. It implies that, having begun receiving wages in full earlier than men, lowwage women caused a widening of the gap in 2000 , which returned to its stable level after the low-wage men also started receiving wages after 2000.

\section{Conclusions}

The paper sheds light on the size and dynamics of Russian gender wage gap before, during and after the 1998 crisis. In the introduction of the paper I argue that the gender wage gap is expected to be closing along with the compression of the wage distribution from the bottom. In spite of this prediction, there is no evidence of a decrease in the differential.

\footnotetext{
${ }^{29}$ The characteristics of the inflows from the sample under arrears into the wage analysis are presented in Appendix A, table 5.
} 
The raw gap exhibits a stable pattern from 1996 through 2002 disrupted by a 10 percentage point increase in 2000 . However, the rise in the gender wage gap can be good news as it might be explained by diminishing wage arrears. In 2000 many more women than men were paid their wages in full relative to 1998 . The women not paid their wages in 1998 enter the wage sample in 2000 and this might have raised the size of the gap as low-paid workers were more likely to be affected by arrears.

However, the analysis-ready sample is subject to different kinds of selection and the multi-stage selectivity correction needs to be applied. However, the results of selectivity correction for participation decision proved to be statistically insignificant, which was also the case in previous studies. In the framework of present analysis I make an attempt to get a deeper insight into the effect of wage arrears on the size of the gap in order to see if the wage arrears are a cause of the increase in the gender wage gap in 2000 . The results of this analysis allow for the deduction that the gap stays stable over time. An increase in the gap in 2000 and its following fall in 2002 are explained by the drop in wage arrears that caused different inflows into the wage sample by quality and gender composition.

Among other findings of the paper is increasing returns to human capital, in general, and to university, in particular. A distinctively robust growth of the returns to university for women might make one expect a closing of the gap, however, the Russian gender wage gap has a source other than the gender differences in returns to the individual characteristics. 
Thus, there are three main findings of the paper. The first is that the wage structure stays stable with respect to gender. The second is that women were less affected by wage arrears due to the fact that they are on average employed in occupations and regions less pervaded by arrears. Finally, the third finding is that the gender composition of the inflow into the wage analysis sample differs in terms of quality that, eventually, caused gender wage gap fluctuations in 2000 and 2002.

In summary, there are two factors that characterize the economic standing of women after the crisis in 1998. First, women benefited more from the drop in wage arrears compared to men. Second, notwithstanding economic growth the gender wage gap persists in its size over time. Overall, the economic growth has had a rather positive impact on the relative position of Russian women. Many more women were paid wages in full in 2000 and the stable size of the gap signifies that their well-being is improved proportionally to the improvements in the society as a whole.

\section{Bibliography}

1. Ashenfelter, Orley and Card, David. Handbook of Labor Economics, Volume 3C, 1999

2. Benitez-Silva, Hugo and Cheidvasser, Sofia. "The educated Russians' curse: returns to education in Russian federation", Yale University Working Paper, 2000 
3. Brainerd, Elizabeth. "Women in transition: changes in gender wage differentials in Eastern Europe and former Soviet Union", Industrial and Labor Relations Review, 54 (1), 2000

4. Brainerd, Elisabeth. "Winners and Losers in Russia's economic transition", American Economic Review, 1998, 88(5), 1094-1116

5. Earle, John S. and Sabirianova, Klara S. "Understanding wage arrears in Russia ", SITE Working Paper No.139, 1999

6. Flanagan, Robert J. "Wage Structure in the Transition of the Czech Economy." International Monetary Fund Stuff Papers, December 1995, 42(4), pp.836-54

7. Friebel, Guido and Guriev, Sergei. "Why Russian workers do not move: attachment of workers via in-kind payments", CEPR Working Paper, 2000, No.2368

8. Gerry, Christopher J.; Kim, Byung-Yeon and A Li, Carmen. "The gender wage gap and wage arrears in Russia: Evidence from the RLMS." Journal of Population Economics, 2004, 17: 267-288

9. Grogan, Louise. "Wage Dispersion in Russia”, Tinbergen Institute Discussion Paper, 1997, No.97-075/3

10. Juhn, Chinhui; Murphy, Kevin M. and Pierce, Brooks. "Wage Inequality and the Rise in Returns to Skill." Journal of Political Economy, June 1993, 101 (3), pp. $410-42$

11. Krueger, Alan B. and Pischke, Joern-Steffen. "A Comparative Analysis of East and West German Labor Markets: Before and After Unification." In Richard 
B.Freeman and Lawrence F.Katz, eds., Differences and changes in wage structures. Chicago: University of Chicago Press, 1995, pp.405-45.

12. Labor Code of Russian Federation, 2001

13. Lehmann, Hartmut, Wadsworth, Jonathan and Acuisti, Alessandro. "Grime and Punishment: Job Insecurity and Wage Arrears in the Russian Federation", Journal of comparative Economics, 27, 595-617 (1999)

14. Mroz, Thomas, Mancini, Dominic and Popkin, Barry. "Monitoring Economic Conditions in the Russian Federation: The Russia Longitudinal Monitoring Survey 1992-2003." Report submitted to the U.S. Agency for International Development. Carolina Population Center, University of North Carolina at Chapel Hill, North Carolina. April 2004.

15. Newell, Andrew and Reilly, Barry. "The gender wage gap in Russia: Some empirical evidence", Labour Economics, 1996, 3, 337-356

16. Ogloblin, Constantin G. "Gender earnings differential in Russia", Industrial and Labor Relations Review, 1999, 52, 4

17. Orazem, Peter F. and Vodopivec, Milan. "Winners and Losers in Transition: Returns to Education, Experience, and Gender in Slovenia." World Bank Economic Review, May 1995, 9(2), pp.201-30

18. Russian Statistic Yearbook, 2001

19. Russian Statistic Yearbook, 2002

20. Reilly, Barry. "The gender pay gap in Russia during the transition, 1992-96", Economics of Transition, 7 (1) 1999, 245-264 
21. Rutkowski, Jan. "High Skills Pay Off: The Changing Wage Structure During Economic transition in Poland." Economics of Transition, May 1996, 4(1), pp.89-111

22. Sabirianova, Klara and Gorodichenko, Yuriy. "Returns to Schooling and Ukraine: A Semiparametric Approach to Cross-country Comparative Analysis", William Davidson Institute Working Paper No.719, September 2004

23. Silber, Jacques and Weber, Michael. "Labor market discrimination: are there significant differencies between the various decomposition procedures?", Applied Economics, 1999, 31, 359-365

24. Vecernik, Jiri. "Changing Earnings Distribution in the Czech Republic" Survey Evidence from 1998-1994." Economics of Transition, September 1995, 3(3), pp.355-71 


\section{Appendix A}

Table 1. Main socio-economic indicators of the living standard of population Indicator 1998 1999 2000 2001

2002

Average per capita money incomes, monthly, rubles

$\begin{array}{lllll}999.6 & 1608.6 & 2192.9 & 2877.3 & 3887\end{array}$

Real disposable money incomes, as percentage of the previous year

$\begin{array}{lllll}83.8 & 85.8 & 109.3 & 105.8 & 108.8\end{array}$

Accrued average monthly nominal wages of employed in the economy, rubles

$\begin{array}{lllll}1051 & 1522.6 & 2223.4 & 3282.0 & 4426\end{array}$

Real accrued wages, as percentage of the previous year

Source: Goskomstat: Handbooks “Russia' 2000", "Russia' 2001", "Russia' 2002"

Table 2. Experience gender difference distribution across age groups ${ }^{\star}$

\begin{tabular}{|c|c|c|c|c|}
\hline & 1996 & 1998 & 2000 & 2002 \\
\hline $\begin{array}{l}\text { Average years of } \\
\text { experience }\end{array}$ & 2.75 & 2.17 & 1.44 & 1.07 \\
\hline \multicolumn{5}{|l|}{$\begin{array}{l}\text { Average years of } \\
\text { experience by age } \\
\text { groups: }\end{array}$} \\
\hline$>=25$ & 0.38 & 0.33 & 0.38 & 0.34 \\
\hline 26-35 & 0.69 & 0.64 & 0.46 & 0.38 \\
\hline $36-45$ & 0.63 & 0.2 & 0.13 & 0.2 \\
\hline$>45$ & 4.28 & 3.66 & 2.4 & 1.49 \\
\hline
\end{tabular}

'experience=age - years of schooling -7 , the gender difference $=X_{m}-X_{f}$, where $\mathrm{m}$ and $\mathrm{f}$ denote male and female respectively 
Table 3. Gender wage ratio, 1998

\begin{tabular}{|c|c|c|}
\hline & $\begin{array}{l}\text { full-time } \\
\text { wage }\end{array}$ & $\begin{array}{c}\text { all } \\
\text { wage }\end{array}$ \\
\hline Australia(2000) & 91 & 89 \\
\hline Austria & 79 & 79 \\
\hline Belgium & 91 & 93 \\
\hline Canada (2000) & 82 & 81 \\
\hline Denmark & 89 & 89 \\
\hline Finland & 82 & 82 \\
\hline France & 87 & 89 \\
\hline Germany & 80 & 81 \\
\hline Greece & 80 & 87 \\
\hline Ireland & 81 & 79 \\
\hline Italy & 85 & 91 \\
\hline Netherlands & 80 & 79 \\
\hline New Zealand (2001) & 86 & 84 \\
\hline Portugal & 92 & 95 \\
\hline Spain & 88 & 86 \\
\hline Sweden (2000) & 86 & 83 \\
\hline Switzerland (2001) & 76 & 78 \\
\hline United Kingdom & 80 & 75 \\
\hline United States (1999) & 79 & 79 \\
\hline OECD unweighted average & 84 & 84 \\
\hline
\end{tabular}

Percentage ratios of female to male wages

Source: European Community Household Panel (ECHP) 
Table 4. The ready-analysis sample formation and characteristics of the excluded, by gender*

\begin{tabular}{|c|c|c|c|c|c|c|c|c|c|c|c|c|}
\hline & \multicolumn{3}{|c|}{1996} & \multicolumn{3}{|c|}{1998} & \multicolumn{3}{|c|}{2000} & \multicolumn{3}{|c|}{2002} \\
\hline & Total & Women & Men & Total & Women & Men & Total & Women & Men & Total & Women & Men \\
\hline Working aged, initial $\mathrm{N}$ & 5914 & $51 \%$ & $49 \%$ & 6099 & $51 \%$ & $49 \%$ & 6450 & $53 \%$ & $47 \%$ & 6606 & $53 \%$ & $47 \%$ \\
\hline Not working & 2042 & $56 \%$ & $44 \%$ & 2327 & $55 \%$ & $45 \%$ & 2359 & $58 \%$ & $42 \%$ & 2727 & $56 \%$ & $44 \%$ \\
\hline Age & 31.57 & 29.94 & 33.61 & 31.72 & 30.28 & 33.46 & 31.42 & 30.50 & 32.68 & 31.26 & 30.46 & 32.28 \\
\hline Years of schooling & 11.32 & 11.55 & 10.98 & 11.47 & 11.69 & 11.19 & 11.54 & 11.72 & 11.28 & 11.60 & 11.78 & 11.37 \\
\hline University & 0.08 & 0.09 & 0.08 & 0.09 & 0.10 & 0.08 & 0.09 & 0.10 & 0.08 & 0.10 & 0.10 & 0.09 \\
\hline Elementary education & 0.29 & 0.25 & 0.33 & 0.27 & 0.23 & 0.32 & 0.26 & 0.23 & 0.31 & 0.21 & 0.18 & 0.25 \\
\hline Owed back wages & 2229 & $48 \%$ & $52 \%$ & 2234 & $50 \%$ & $50 \%$ & 1172 & $46 \%$ & $54 \%$ & 1617 & $47 \%$ & $53 \%$ \\
\hline Age & 38.34 & 36.96 & 39.62 & 38.25 & 37.71 & 38.81 & 38.17 & 37.59 & 38.66 & 38.31 & 38.82 & 37.86 \\
\hline Years of schooling & 12.04 & 12.43 & 11.69 & 12.26 & 12.70 & 11.83 & 12.23 & 12.66 & 11.87 & 12.42 & 12.97 & 11.92 \\
\hline University & 0.18 & 0.20 & 0.16 & 0.20 & 0.23 & 0.16 & 0.18 & 0.22 & 0.14 & 0.19 & 0.25 & 0.14 \\
\hline Elementary education & 0.18 & 0.12 & 0.24 & 0.18 & 0.12 & 0.24 & 0.18 & 0.13 & 0.22 & 0.17 & 0.12 & 0.22 \\
\hline Analysis-ready sample, $\mathrm{N}$ & 1023 & $54 \%$ & $46 \%$ & 890 & $53 \%$ & $47 \%$ & 1943 & $54 \%$ & $46 \%$ & 2643 & $53 \%$ & $47 \%$ \\
\hline
\end{tabular}

*the numbers of the excluded and the included should not necessarily sum up the initial number of the working aged individuals as there are other reasons to eliminate observations, such as not reporting wage or/and hours worked etc. 


\section{Table 5. Human capital characteristics of the sample under analysis by gender}

\begin{tabular}{|c|c|c|c|c|c|c|c|c|}
\hline & \multicolumn{2}{|c|}{1996} & \multicolumn{2}{|c|}{1998} & \multicolumn{2}{|c|}{2000} & \multicolumn{2}{|c|}{2002} \\
\hline & Women & Men & Women & Men & Women & Men & Women & Men \\
\hline \multicolumn{9}{|l|}{ Education : } \\
\hline High school & 90.91 & 82.24 & 89.89 & 84.34 & 86.49 & 79.48 & 86.64 & 80.53 \\
\hline $\begin{array}{l}\text { Vocational education } \\
\text { w/o secondary }\end{array}$ & 6.54 & 12.05 & 5.68 & 11.81 & 6.66 & 11.55 & 6.39 & 9.58 \\
\hline $\begin{array}{l}\text { Vocational education } \\
\text { with secondary }\end{array}$ & 14.73 & 19.03 & 15.16 & 22.17 & 15.60 & 25.56 & 15.71 & 21.63 \\
\hline Specialized education & 36.91 & 19.24 & 39.16 & 21.93 & 39.68 & 20.96 & 31.27 & 16.83 \\
\hline University & 26.54 & 24.95 & 27.37 & 25.78 & 25.88 & 21.75 & 19.47 & 16.14 \\
\hline Graduate education & 0.90 & 0.21 & 0.63 & 1.44 & 1.24 & 0.22 & 0.65 & 0.57 \\
\hline $\begin{array}{l}\text { Average number of } \\
\text { school years }\end{array}$ & 12.95 & 12.53 & 13.09 & 13.03 & 13.03 & 12.59 & 12.50 & 11.98 \\
\hline $\begin{array}{l}\text { Average years of } \\
\text { experience }\end{array}$ & 15.41 & 17.75 & 18.26 & 18.11 & 18.22 & 18.08 & 15.51 & 16.58 \\
\hline \multicolumn{9}{|l|}{$\begin{array}{l}\text { individuals by years of } \\
\text { experience, \%: }\end{array}$} \\
\hline $0-4$ & 12.18 & 13.53 & 10.74 & 13.01 & 13.03 & 13.90 & 25.53 & 22.29 \\
\hline 5-9 & 15.82 & 14.38 & 12.84 & 13.25 & 11.13 & 14.57 & 11.63 & 12.85 \\
\hline $10-19$ & 38.73 & 32.13 & 26.95 & 29.16 & 26.55 & 27.13 & 23.30 & 22.91 \\
\hline $20-29$ & 28.91 & 24.52 & 37.89 & 29.16 & 33.78 & 25.90 & 24.61 & 24.73 \\
\hline More than 30 years & 4.72 & 15.86 & 12.21 & 16.14 & 16.08 & 18.95 & 15.31 & 17.51 \\
\hline
\end{tabular}

${ }^{\circ}$ calculated for those who worked during 30 days preceding the interview and were not affected by wage arrears 
Table 6. The characteristics of those who enter the wage-analysis sample

\begin{tabular}{|c|c|c|c|c|}
\hline Characteristics & 2000 & 998 & 2002 & 000 \\
\hline & Women & Men & Women & Men \\
\hline Experience & 20.76 & 21.03 & 20.49 & 20.54 \\
\hline University & 24.90 & 20.54 & 27.54 & 19.32 \\
\hline Specialized secondary & 38.22 & 16.03 & 33.53 & 17.61 \\
\hline Vocational training with secondary education & 10.04 & 23.25 & 10.18 & 23.30 \\
\hline Vocational training without secondary education & 5.60 & 10.38 & 5.99 & 11.36 \\
\hline Incomplete secondary & 13.90 & 20.32 & 8.38 & 15.34 \\
\hline Professionals & 33.59 & 17.83 & 32.93 & 16.48 \\
\hline Technicians & 26.83 & 6.32 & 24.55 & 6.25 \\
\hline Clerks & 8.69 & 1.35 & 10.78 & 1.14 \\
\hline Service workers & 10.04 & 5.19 & 7.19 & 3.98 \\
\hline Craft/plant workers & 11.00 & 63.88 & 12.57 & 61.36 \\
\hline Unskilled & 9.85 & 4.97 & 11.38 & 9.66 \\
\hline $\begin{array}{l}\text { Percentage by wage distribution quartile } \\
1^{\text {st }}\end{array}$ & 25.70 & 19.32 & 14.19 & 18.43 \\
\hline $2^{\text {nd }}$ & 30.24 & 28.10 & 11.57 & 16.18 \\
\hline $3^{\text {rd }}$ & 31.30 & 29.32 & 11.62 & 11.08 \\
\hline $4^{\text {th }}$ & 27.41 & 25.16 & 8.94 & 12.94 \\
\hline
\end{tabular}




\section{Appendix B}

Table1. Estimated coefficients for 1996-year sample

\begin{tabular}{|c|c|c|c|}
\hline & POOLED & FEMALE & MALE \\
\hline Number of observations & 1023 & 550 & 473 \\
\hline & \multicolumn{3}{|c|}{ Model 1} \\
\hline R-squared & 0.043 & 0.066 & 0.053 \\
\hline Experience & 0.001 & 0.015 & 0.000 \\
\hline Experience squared & -0.017 & -0.053 & -0.015 \\
\hline University & $0.277^{* * *}$ & $0.255^{* \star *}$ & $0.327^{\star \star *}$ \\
\hline $\begin{array}{l}\text { Specialized secondary } \\
\text { Vocational training with secondary }\end{array}$ & 0.101 & 0.106 & $0.263^{* *}$ \\
\hline education & -0.065 & -0.115 & -0.023 \\
\hline secondary education & 0.042 & -0.098 & 0.121 \\
\hline Incomplete secondary & $-0.196^{\star \star}$ & $-0.311^{* * *}$ & -0.179 \\
\hline Constant & $10.303^{* * *}$ & $10.091^{* * *}$ & $10.422^{* * *}$ \\
\hline \multicolumn{4}{|c|}{ Model 2} \\
\hline R-squared & 0.082 & 0.088 & 0.101 \\
\hline Experience & 0.001 & 0.012 & 0.003 \\
\hline Experience squared & -0.020 & -0.045 & -0.025 \\
\hline University & $0.258^{* * *}$ & 0.175 & 0.170 \\
\hline $\begin{array}{l}\text { Specialized secondary } \\
\text { Vocational training with secondary }\end{array}$ & 0.113 & 0.082 & 0.203 \\
\hline $\begin{array}{l}\text { education } \\
\text { Vocational training without }\end{array}$ & -0.083 & -0.133 & -0.019 \\
\hline secondary education & -0.007 & -0.126 & 0.094 \\
\hline Incomplete secondary & $-0.195^{\star *}$ & $-0.2928^{\star * *}$ & $-0.198^{*}$ \\
\hline Professionals & $0.299^{* * *}$ & $0.337^{\star *}$ & $0.465^{\star \star \star}$ \\
\hline Technicians & $0.272^{* *}$ & $0.245^{*}$ & $0.767^{* * *}$ \\
\hline Clerks & 0.018 & 0.145 & -0.123 \\
\hline Service workers & 0.116 & 0.190 & 0.134 \\
\hline Craft/plant workers & $0.443^{* * *}$ & $0.434^{\star \star *}$ & $0.359^{* \star *}$ \\
\hline Constant & $10.064^{* * *}$ & $9.892^{* * *}$ & $10.126^{\star * *}$ \\
\hline \multicolumn{4}{|c|}{ Model 3} \\
\hline R-squared & 0.359 & 0.378 & 0.438 \\
\hline Experience & 0.006 & 0.017 & 0.010 \\
\hline Experience squared & -0.029 & $-0.055^{*}$ & $-0.042^{*}$ \\
\hline University & $0.226^{* * *}$ & 0.150 & 0.122 \\
\hline Specialized secondary & $0.144^{* *}$ & 0.111 & $0.260^{\star \star}$ \\
\hline $\begin{array}{l}\text { Vocational training with secondary } \\
\text { education } \\
\text { Vocational training without }\end{array}$ & -0.023 & -0.066 & -0.017 \\
\hline secondary education & 0.011 & -0.049 & 0.026 \\
\hline Incomplete secondary & -0.077 & -0.124 & -0.109 \\
\hline Technicians & $0.226^{* *}$ & $0.271^{* *}$ & $0.606^{\star * *}$ \\
\hline
\end{tabular}




\begin{tabular}{|c|c|c|c|}
\hline & POOLED & FEMALE & MALE \\
\hline Professionals & $0.303^{* * *}$ & $0.425^{\star * *}$ & $0.345^{\star \star \star}$ \\
\hline Clerks & 0.010 & 0.164 & -0.065 \\
\hline Service workers & 0.084 & 0.184 & 0.073 \\
\hline Craft/plant workers & $0.399^{* * *}$ & $0.419^{\star * *}$ & $0.268^{\star * *}$ \\
\hline Rural area & $-0.249^{\star \star *}$ & -0.170 & $-0.283^{* *}$ \\
\hline Moscow city & $0.335^{* * *}$ & $0.508^{* * *}$ & 0.125 \\
\hline Altai krai & -0.160 & 0.067 & -0.386 \\
\hline Amur oblast & -0.122 & 0.088 & -0.475 \\
\hline Cheliabinsk oblast & -0.134 & -0.210 & -0.130 \\
\hline Chuvash republic & $-1.068^{* * *}$ & $-0.584^{* * *}$ & $-1.587^{* * *}$ \\
\hline Kabardino-Balkar republic & $-0.929^{* * *}$ & $-0.501^{* * *}$ & $-1.500^{* * *}$ \\
\hline Kaluga oblast & $-0.671^{* * *}$ & $-0.517^{*}$ & $-0.863^{* * *}$ \\
\hline Khanty-mansi autonomous okrug & $0.907^{* * *}$ & $0.992^{* * *}$ & $0.812^{* * *}$ \\
\hline Komi republic & $0.593^{* * *}$ & $0.567^{\star \star *}$ & $0.676^{\star \star \star}$ \\
\hline Krasnodar krai & $-0.349^{* * *}$ & $-0.315^{\star}$ & $-0.413^{* *}$ \\
\hline Krasnoyarsk krai & 0.252 & $0.523^{* *}$ & -0.146 \\
\hline Kurgan oblast & $-0.342^{* *}$ & $-0.282^{*}$ & -0.186 \\
\hline Leningrad oblast & $-0.318^{\star *}$ & 0.081 & $-0.627^{\star * *}$ \\
\hline Lipetsk oblast & $-0.344^{* * *}$ & $-0.288^{*}$ & $-0.320^{\star *}$ \\
\hline Nizhny Novgorod oblast & $-0.493^{* * *}$ & $-0.399^{* *}$ & -0.307 \\
\hline Orienburg oblast & -0.012 & 0.195 & -0.255 \\
\hline Penza oblast & $-0.775^{\star * *}$ & -0.024 & $-1.077^{* * *}$ \\
\hline Perm oblast & $-0.188^{* * *}$ & -0.216 & -0.100 \\
\hline Primorskii krai & $0.425^{* * *}$ & $0.415^{\star * *}$ & $0.621^{* * *}$ \\
\hline Rostov oblast & $-0.488^{* * *}$ & $-0.592^{* \star *}$ & $-0.399^{*}$ \\
\hline Saratov oblast & $-0.497^{* * *}$ & $-0.381^{*}$ & $-0.657^{* * *}$ \\
\hline Smolensk oblast & $-0.377^{\star * \star}$ & -0.237 & $-0.540^{* *}$ \\
\hline St-Petersburg city & -0.132 & 0.034 & $-0.331^{*}$ \\
\hline Stavropol krai & $-0.347^{*}$ & 0.265 & $-0.903^{* * *}$ \\
\hline Tambov oblast & -0.403 & $-0.327^{* *}$ & -0.604 \\
\hline Tatar republic & $-0.388^{* * *}$ & $-0.348^{* *}$ & $-0.533^{* * *}$ \\
\hline Tomsk oblast & 0.054 & 0.224 & -0.202 \\
\hline Tula oblast & $-0.510^{\star \star *}$ & $-0.470^{* * *}$ & $-0.444^{*}$ \\
\hline Tver oblast & $-0.550^{\star \star *}$ & -0.359 & $-0.764^{* \star *}$ \\
\hline Udmurtia oblast & $-0.315^{\star *}$ & -0.098 & $-0.602^{* * *}$ \\
\hline Volgograd oblast & $-0.871^{* * *}$ & $-0.565^{\star \star *}$ & $-1.574^{* * *}$ \\
\hline Constant & $10.137^{* * *}$ & $9.802^{* * *}$ & $10.418^{* * *}$ \\
\hline
\end{tabular}


Table 2. Estimated coefficients for the 1998-year sample

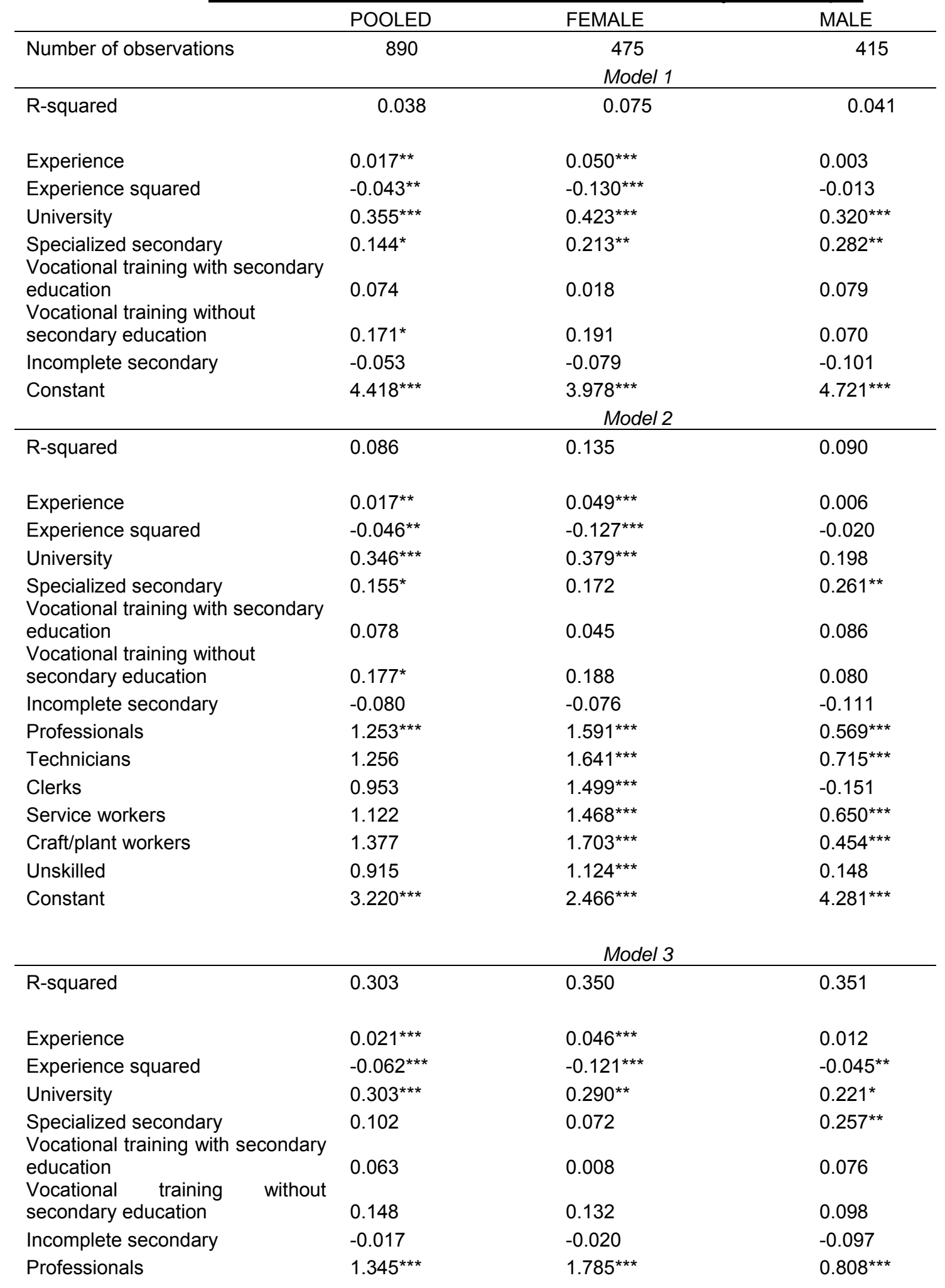




\begin{tabular}{|c|c|c|c|}
\hline & POOLED & FEMALE & MALE \\
\hline Technicians & $1.363^{* \star *}$ & $1.825^{\star \star \star}$ & $0.996^{\star * *}$ \\
\hline Clerks & $1.048^{* * *}$ & $1.649^{* * *}$ & 0.070 \\
\hline Service workers & $1.229^{\star * *}$ & $1.651^{* * *}$ & $0.886^{\star * *}$ \\
\hline Craft/plant workers & $1.486^{\star * *}$ & $1.852^{* * *}$ & $0.778^{\star \star *}$ \\
\hline Unskilled & $1.034^{* * *}$ & $1.296^{* * *}$ & $0.554^{\star * *}$ \\
\hline Rural area & $-0.461^{\star * *}$ & $-0.447^{* * *}$ & -0.236 \\
\hline Moscow city & 0.050 & 0.037 & 0.119 \\
\hline Altai krai & $-0.397^{\star * *}$ & $-0.446^{* *}$ & -0.320 \\
\hline Amur oblast & $-0.614^{* * *}$ & $-0.595^{*}$ & $-0.710^{* *}$ \\
\hline Cheliabinsk oblast & -0.096 & -0.250 & -0.032 \\
\hline Chuvash republic & $-0.608^{* *}$ & -0.478 & -0.813 \\
\hline Kabardino-Balkar republic & $-0.506^{*}$ & $-0.823^{* * *}$ & -0.186 \\
\hline Kaluga oblast & $-0.877^{* \star *}$ & $-0.976^{* * *}$ & $-1.129^{* * *}$ \\
\hline Khanty-mansi autonomous okrug & $0.767^{* * *}$ & $0.792^{* * *}$ & $0.826^{\star \star *}$ \\
\hline Komi republic & 0.258 & 0.279 & 0.272 \\
\hline Krasnodar krai & $-0.313^{* *}$ & $-0.384^{* *}$ & -0.229 \\
\hline Krasnoyarsk krai & 0.015 & 0.114 & 0.079 \\
\hline Kurgan oblast & $-0.252^{\star \star}$ & $-0.435^{\star \star \star}$ & -0.031 \\
\hline Leningrad oblast & -0.311 & -0.196 & -0.233 \\
\hline Lipetsk oblast & $-0.384^{\star * *}$ & $-0.331^{* *}$ & $-0.299^{*}$ \\
\hline Nizhny Novgorod oblast & $-0.477^{\star \star \star}$ & $-0.552^{* * *}$ & -0.165 \\
\hline Orienburg oblast & $-0.410^{\star * *}$ & $-0.375^{\star *}$ & $-0.371^{* *}$ \\
\hline Penza oblast & $-0.513^{* * *}$ & -0.178 & $-0.704^{* * *}$ \\
\hline Perm oblast & $-0.234^{\star *}$ & $-0.310^{*}$ & 0.007 \\
\hline Primorskii krai & -0.096 & -0.219 & 0.114 \\
\hline Rostov oblast & $-0.496^{* * *}$ & $-0.606^{* * *}$ & $-0.303^{*}$ \\
\hline Saratov oblast & $-0.691^{* * *}$ & $-0.506^{* * *}$ & $-0.811^{* * *}$ \\
\hline Smolensk oblast & $-0.458^{* * *}$ & $-0.304^{*}$ & $-0.668^{* *}$ \\
\hline St-Petersburg city & $-0.255^{\star \star}$ & $-0.293^{*}$ & -0.112 \\
\hline Stavropol krai & $-0.486^{\star * *}$ & $-0.345^{\star *}$ & $-0.779^{* * *}$ \\
\hline Tambov oblast & $-1.213^{\star \star *}$ & -0.981 & $-1.500^{* * *}$ \\
\hline Tatar republic & $-0.582^{* * *}$ & -0.263 & $-0.796^{\star * *}$ \\
\hline Tomsk oblast & -0.063 & 0.249 & -0.146 \\
\hline Tula oblast & $-0.551^{* * *}$ & $-0.584^{* * *}$ & $-0.377^{* *}$ \\
\hline Tver oblast & -0.277 & -0.120 & $-0.482^{*}$ \\
\hline Udmurtia oblast & $-0.554^{* * *}$ & $-0.420^{* * *}$ & $-0.575^{\star *}$ \\
\hline Volgograd oblast & $-0.784^{* * *}$ & $-0.665^{* * *}$ & $-0.964^{* * *}$ \\
\hline Constant & $3.415^{\star \star \star}$ & $2.664^{* * *}$ & $4.167^{\star * *}$ \\
\hline
\end{tabular}


Table3. Estimated coefficients for 2000-year sample

\begin{tabular}{|c|c|c|c|}
\hline & POOLED & FEMALE & MALE \\
\hline Number of observations & 1943 & 1051 & 892 \\
\hline & \multicolumn{3}{|c|}{ Model 1} \\
\hline R-squared & 0.059 & 0.092 & 0.071 \\
\hline Experience & $0.034^{\star * *}$ & $0.034^{\star * \star}$ & $0.047^{\star \star *}$ \\
\hline Experience squared & $-0.079^{* * *}$ & $-0.080^{* * *}$ & $-0.108^{* * *}$ \\
\hline University & $0.435^{\star * *}$ & $0.589^{* * *}$ & $0.340^{\star * *}$ \\
\hline $\begin{array}{l}\text { Specialized secondary } \\
\text { Vocational training with secondary }\end{array}$ & 0.052 & $0.173^{\star *}$ & $0.180^{\star \star}$ \\
\hline & $0.162^{* *}$ & $0.218^{* *}$ & 0.050 \\
\hline secondary education & 0.039 & 0.074 & -0.034 \\
\hline Incomplete secondary & -0.019 & -0.051 & -0.063 \\
\hline \multirow[t]{2}{*}{ Constant } & $4.271^{* \star *}$ & $4.000^{* * *}$ & $4.450^{* * *}$ \\
\hline & \multicolumn{3}{|c|}{ Model 2} \\
\hline R-squared & 0.128 & 0.127 & 0.113 \\
\hline Experience & $0.033^{\star \star *}$ & $0.035^{\star \star *}$ & $0.041^{\star \star *}$ \\
\hline Experience squared & $-0.079^{\star \star *}$ & $-0.085^{\star \star *}$ & $-0.096^{* * *}$ \\
\hline University & $0.477^{* * *}$ & $0.527^{\star * *}$ & $0.300^{* * *}$ \\
\hline $\begin{array}{l}\text { Specialized secondary } \\
\text { Vocational training with secondary }\end{array}$ & 0.076 & 0.088 & $0.163^{\star \star}$ \\
\hline $\begin{array}{l}\text { education } \\
\text { Vocational training without }\end{array}$ & $0.109^{*}$ & $0.196^{* *}$ & 0.019 \\
\hline secondary education & -0.016 & 0.029 & -0.040 \\
\hline Incomplete secondary & -0.024 & -0.013 & -0.055 \\
\hline Professionals & -0.155 & $0.650^{* * *}$ & 0.082 \\
\hline Technicians & -0.112 & $0.788^{* * *}$ & 0.028 \\
\hline Clerks & -0.275 & $0.685^{\star * *}$ & -0.297 \\
\hline Service workers & -0.397 & $0.481^{* \star *}$ & -0.193 \\
\hline Craft/plant workers & 0.181 & $0.848^{* * *}$ & 0.106 \\
\hline Unskilled & $-0.511^{*}$ & $0.300^{* * *}$ & -0.479 \\
\hline \multirow[t]{2}{*}{ Constant } & $4.402^{* * *}$ & $3.386^{* * *}$ & $4.505^{\star * *}$ \\
\hline & \multicolumn{3}{|c|}{ Model 3} \\
\hline R-squared & 0.407 & 0.400 & 0.446 \\
\hline Experience & $0.031^{* * *}$ & $0.034^{\star \star *}$ & $0.035^{\star * *}$ \\
\hline Experience squared & $-0.078^{* * *}$ & $-0.083^{* * *}$ & $-0.087^{* * *}$ \\
\hline University & $0.436^{* * *}$ & $0.461^{* * *}$ & $0.330^{* * *}$ \\
\hline $\begin{array}{l}\text { Specialized secondary } \\
\text { Vocational training with secondary }\end{array}$ & $0.142^{* * *}$ & $0.142^{* *}$ & $0.218^{\star * *}$ \\
\hline $\begin{array}{l}\text { education } \\
\text { Vocational training without }\end{array}$ & $0.133^{* * *}$ & $0.216^{* * *}$ & 0.042 \\
\hline secondary education & 0.020 & 0.114 & -0.026 \\
\hline Incomplete secondary & -0.009 & 0.015 & -0.071 \\
\hline Professionals & -0.284 & $1.166^{* * *}$ & -0.374 \\
\hline Technicians & -0.356 & $1.172^{* * *}$ & $-0.470^{*}$ \\
\hline
\end{tabular}




\begin{tabular}{|c|c|c|c|}
\hline \multicolumn{4}{|l|}{ Table 3. (continued) } \\
\hline & POOLED & FEMALE & MALE \\
\hline Clerks & -0.442 & $1.112^{\star * *}$ & $-0.530^{*}$ \\
\hline Service workers & $-0.604^{* *}$ & $0.862^{* * *}$ & $-0.542^{* *}$ \\
\hline Craft/plant workers & -0.019 & $1.268^{* * *}$ & -0.300 \\
\hline Unskilled & $-0.636^{* *}$ & $0.799^{\star * *}$ & $-0.831^{* * *}$ \\
\hline Rural area & $-0.290^{\star \star *}$ & $-0.176^{\star *}$ & $-0.365^{\star * *}$ \\
\hline Moscow city & 0.021 & 0.118 & -0.111 \\
\hline Altai krai & $-0.825^{* * *}$ & $-0.867^{* * *}$ & $-0.870^{* * *}$ \\
\hline Amur oblast & $-1.294^{\star \star \star}$ & $-1.006^{* * *}$ & $-1.610^{* * *}$ \\
\hline Cheliabinsk oblast & $-0.554^{\star \star \star}$ & $-0.603^{* * *}$ & $-0.554^{* * *}$ \\
\hline Chuvash republic & $-1.367^{* \star *}$ & $-1.192^{* * *}$ & $-1.554^{* * *}$ \\
\hline Kabardino-Balkar republic & $-0.855^{\star \star \star}$ & $-0.854^{* * *}$ & $-0.878^{* * *}$ \\
\hline Kaluga oblast & $-0.883^{\star * \star}$ & $-0.710^{* * *}$ & $-1.202^{* * *}$ \\
\hline Khanty-mansi autonomous okrug & $0.659^{* * *}$ & $0.646^{\star * *}$ & $0.702^{* * *}$ \\
\hline Komi republic & $0.212^{*}$ & 0.142 & 0.267 \\
\hline Krasnodar krai & $-0.683^{\star \star \star}$ & $-0.773^{* * *}$ & $-0.657^{* * *}$ \\
\hline Krasnoyarsk krai & $-0.279^{\star \star \star}$ & $-0.248^{* *}$ & $-0.284^{* *}$ \\
\hline Kurgan oblast & $-0.800^{* * *}$ & $-0.812^{* * *}$ & $-0.725^{* * *}$ \\
\hline Leningrad oblast & $-0.392^{\star \star \star}$ & $-0.331^{* *}$ & $-0.499^{* * *}$ \\
\hline Lipetsk oblast & $-0.639^{* \star *}$ & $-0.769^{* * *}$ & $-0.508^{* * *}$ \\
\hline Nizhny Novgorod oblast & $-0.695^{\star * *}$ & $-0.586^{\star * *}$ & $-0.759^{* * *}$ \\
\hline Orienburg oblast & $-0.604^{* * *}$ & $-0.683^{* * *}$ & $-0.514^{* * *}$ \\
\hline Penza oblast & $-1.177^{\star * *}$ & $-1.305^{* * *}$ & $-0.959^{* * *}$ \\
\hline Perm oblast & $-0.291^{* * *}$ & $-0.519^{\star * *}$ & $-0.117^{* * *}$ \\
\hline Primorskii krai & -0.057 & -0.090 & -0.105 \\
\hline Rostov oblast & $-0.470^{* * *}$ & $-0.540^{* * *}$ & $-0.399^{* * *}$ \\
\hline Saratov oblast & $-0.810^{* * *}$ & $-0.702^{* * *}$ & $-0.925^{* * *}$ \\
\hline Smolensk oblast & $-0.740^{\star \star \star}$ & $-0.603^{* * *}$ & $-0.877^{* * *}$ \\
\hline St-Petersburg city & -0.191 & -0.046 & $-0.393^{* * *}$ \\
\hline Stavropol krai & $-1.339^{* * *}$ & $-1.127^{* * *}$ & $-1.565^{\star * *}$ \\
\hline Tambov oblast & $-0.930^{* * *}$ & $-0.935^{\star * *}$ & $-0.804^{\star * *}$ \\
\hline Tatar republic & $-0.878^{* \star *}$ & $-0.909^{* * *}$ & $-0.895^{\star * *}$ \\
\hline Tomsk oblast & $-0.408^{* * *}$ & $-0.347^{* * *}$ & $-0.377^{*}$ \\
\hline Tula oblast & $-0.533^{\star \star *}$ & $-0.597^{\star \star \star}$ & $-0.530^{\star * *}$ \\
\hline Tver oblast & $-0.727^{\star \star *}$ & $-0.677^{\star \star *}$ & $-0.798^{\star * *}$ \\
\hline Udmurtia oblast & $-0.917^{* * *}$ & $-0.807^{* * *}$ & $-1.037^{* * *}$ \\
\hline Volgograd oblast & $-1.081^{* * *}$ & $-1.050^{\star * *}$ & $-0.986^{* * *}$ \\
\hline Constant & $5.128^{* * *}$ & $3.466^{* * *}$ & $5.503^{\star * *}$ \\
\hline
\end{tabular}


Table4. Estimated coefficients for 2002-year sample

\begin{tabular}{|c|c|c|c|}
\hline & POOLED & FEMALE & MALE \\
\hline Number of observations & 2643 & 1395 & 1248 \\
\hline & \multicolumn{3}{|c|}{ Model 1} \\
\hline R-squared & 0.071 & 0.099 & 0.082 \\
\hline Experience & $0.014^{* * *}$ & 0.008 & $0.021^{* * *}$ \\
\hline Experience squared & $-0.031^{* * *}$ & -0.015 & $-0.049^{* * *}$ \\
\hline University & $0.499^{* * *}$ & $0.555^{\star * *}$ & $0.522^{\star \star *}$ \\
\hline $\begin{array}{l}\text { Specialized secondary } \\
\text { Vocational training with secondary }\end{array}$ & $0.128^{* * *}$ & $0.199^{* * *}$ & $0.232^{* * *}$ \\
\hline & $0.106^{* * *}$ & $0.106^{*}$ & 0.083 \\
\hline secondary education & 0.090 & 0.074 & 0.074 \\
\hline Incomplete secondary & -0.023 & $-0.121^{* *}$ & -0.023 \\
\hline \multirow[t]{2}{*}{ Constant } & $5.501^{* * *}$ & $5.339^{* * *}$ & $5.622^{* * *}$ \\
\hline & \multicolumn{3}{|c|}{ Model 2} \\
\hline R-squared & 0.121 & 0.126 & 0.13 \\
\hline Experience & $0.014^{\star * *}$ & 0.007 & $0.021^{* * *}$ \\
\hline Experience squared & $-0.034^{* * *}$ & -0.015 & $-0.053^{* * *}$ \\
\hline University & $0.478^{* * *}$ & $0.437^{* * *}$ & $0.432^{* * *}$ \\
\hline Specialized secondary & $0.124^{* * *}$ & $0.123^{* *}$ & $0.204^{* * *}$ \\
\hline $\begin{array}{l}\text { Vocational training with secondary } \\
\text { education }\end{array}$ & $0.083^{* *}$ & $0.097^{*}$ & 0.066 \\
\hline $\begin{array}{l}\text { Vocational training without } \\
\text { secondary education }\end{array}$ & 0.076 & 0.068 & 0.058 \\
\hline Incomplete secondary & -0.011 & -0.079 & 0.001 \\
\hline Professionals & $0.571^{* *}$ & $0.558^{\star * *}$ & $0.835^{\star \star *}$ \\
\hline Technicians & $0.480^{*}$ & $0.498^{* * *}$ & $0.740^{\star \star *}$ \\
\hline Clerks & $0.548^{* *}$ & $0.591^{* * *}$ & $0.915^{* \star *}$ \\
\hline Service workers & 0.366 & $0.340^{\star * *}$ & $0.753^{* * *}$ \\
\hline Craft/plant workers & $0.695^{\star * *}$ & $0.526^{* * *}$ & $0.761^{* * *}$ \\
\hline Unskilled & 0.172 & $0.187^{* *}$ & 0.260 \\
\hline \multirow[t]{2}{*}{ Constant } & $4.995^{\star * *}$ & $4.924^{\star \star *}$ & $4.937^{\star \star \star}$ \\
\hline & \multicolumn{3}{|c|}{ Model 3} \\
\hline R-squared & 0.281 & 0.287 & 0.320 \\
\hline Experience & $0.020^{* * *}$ & $0.014^{* *}$ & $0.026^{\star \star *}$ \\
\hline Experience squared & $-0.053^{\star * *}$ & $-0.033^{* *}$ & $-0.067^{* * *}$ \\
\hline University & $0.426^{* * *}$ & $0.387^{* * *}$ & $0.387^{* \star *}$ \\
\hline Specialized secondary & $0.121^{* * *}$ & $0.127^{* * *}$ & $0.168^{* * *}$ \\
\hline $\begin{array}{l}\text { Vocational training with secondary } \\
\text { education } \\
\text { Vocational training without }\end{array}$ & 0.053 & 0.064 & 0.034 \\
\hline secondary education & 0.076 & 0.080 & 0.058 \\
\hline Incomplete secondary & 0.038 & -0.013 & 0.015 \\
\hline Professionals & $0.360^{*}$ & $0.466^{* * *}$ & $0.468^{*}$ \\
\hline Technicians & 0.268 & $0.396^{* * *}$ & 0.377 \\
\hline Clerks & 0.296 & $0.449^{* * *}$ & $0.518^{\star *}$ \\
\hline
\end{tabular}




\begin{tabular}{|c|c|c|c|}
\hline \multicolumn{4}{|l|}{ Table 4. (continued) } \\
\hline & POOLED & FEMALE & MALE \\
\hline Service workers & 0.150 & $0.213^{* *}$ & $0.456^{*}$ \\
\hline Craft/plant workers & $0.513^{* * *}$ & $0.456^{* * *}$ & $0.457^{*}$ \\
\hline Unskilled & 0.005 & 0.093 & 0.007 \\
\hline Rural area & $-0.251^{\star \star \star}$ & $-0.211^{* * *}$ & $-0.292^{* * *}$ \\
\hline Moscow city & $0.133^{* *}$ & 0.108 & 0.142 \\
\hline Altai krai & $-0.398^{* * *}$ & $-0.329^{\star * *}$ & $-0.506^{* * *}$ \\
\hline Amur oblast & $-0.272^{\star \star}$ & $-0.301^{*}$ & -0.195 \\
\hline Cheliabinsk oblast & $-0.184^{* *}$ & $-0.301^{* * *}$ & -0.040 \\
\hline Chuvash republic & $-0.599^{* * *}$ & $-0.567^{* * *}$ & $-0.552^{* * *}$ \\
\hline Kabardino-Balkar republic & $-0.558^{* * *}$ & $-0.548^{* * *}$ & $-0.514^{\star * *}$ \\
\hline Kaluga oblast & $-0.422^{* * *}$ & -0.098 & $-0.699^{* * *}$ \\
\hline Khanty-mansi autonomous okrug & $0.702^{* * *}$ & $0.649^{* * *}$ & $0.797^{* * *}$ \\
\hline Komi republic & $0.316^{* * *}$ & $0.315^{\star * *}$ & $0.363^{* * *}$ \\
\hline Krasnodar krai & $-0.311^{* * *}$ & $-0.274^{* * *}$ & $-0.376^{\star * *}$ \\
\hline Krasnoyarsk krai & 0.073 & -0.020 & $0.220^{* *}$ \\
\hline Kurgan oblast & $-0.308^{* * *}$ & -0.108 & $-0.491^{* * *}$ \\
\hline Leningrad oblast & 0.009 & -0.037 & 0.105 \\
\hline Lipetsk oblast & $-0.213^{*}$ & $-0.266^{\star * *}$ & -0.100 \\
\hline Nizhny Novgorod oblast & -0.130 & -0.168 & -0.074 \\
\hline Orienburg oblast & $-0.412^{* * *}$ & $-0.374^{* * *}$ & $-0.393^{* * *}$ \\
\hline Penza oblast & $-0.715^{\star * \star}$ & $-0.599^{* * *}$ & $-0.772^{* * *}$ \\
\hline Perm oblast & -0.130 & $-0.230^{* *}$ & 0.084 \\
\hline Primorskii krai & 0.066 & 0.053 & 0.094 \\
\hline Rostov oblast & $-0.156^{*}$ & $-0.207^{*}$ & -0.095 \\
\hline Saratov oblast & $-0.332^{\star * *}$ & $-0.301^{* * *}$ & $-0.332^{* * *}$ \\
\hline Smolensk oblast & $-0.382^{* * *}$ & $-0.406^{* * *}$ & $-0.256^{* *}$ \\
\hline St-Petersburg city & 0.122 & $0.172^{*}$ & 0.036 \\
\hline Stavropol krai & $-0.570^{\star * *}$ & $-0.518^{* * *}$ & $-0.611^{* * *}$ \\
\hline Tambov oblast & $-0.604^{\star * *}$ & $-0.599^{* * *}$ & $-0.572^{* * *}$ \\
\hline Tatar republic & $-0.236^{\star * *}$ & $-0.264^{* * *}$ & $-0.236^{\star *}$ \\
\hline Tomsk oblast & -0.043 & -0.051 & -0.011 \\
\hline Tula oblast & $-0.174^{\star *}$ & $-0.241^{* *}$ & -0.063 \\
\hline Tver oblast & $-0.287^{\star \star *}$ & $-0.359^{* * *}$ & $-0.216^{*}$ \\
\hline Udmurtia oblast & $-0.143^{*}$ & $-0.243^{* *}$ & -0.008 \\
\hline Volgograd oblast & $-0.643^{* * *}$ & $-0.637^{* * *}$ & $-0.565^{\star * *}$ \\
\hline Constant & $5.358^{* \star *}$ & $5.192^{* \star *}$ & $5.401^{* * *}$ \\
\hline
\end{tabular}


Individual researchers, as well as the on-line and printed versions of the CERGE-EI Working Papers (including their dissemination) were supported from the following institutional grants:

- Economic Aspects of EU and EMU Entry [Ekonomické aspekty vstupu do Evropské unie a Evropské měnové unie], No. AVOZ70850503, (2005-2010);

- Economic Impact of European Integration on the Czech Republic [Ekonomické dopady evropské integrace na ČR], No. MSM0021620846, (2005-2011);

Specific research support and/or other grants the researchers/publications benefited from are acknowledged at the beginning of the Paper.

(c) Elena Kazakova, 2005

All rights reserved. No part of this publication may be reproduced, stored in a retrieval system or transmitted in any form or by any means, electronic, mechanical or photocopying, recording, or otherwise without the prior permission of the publisher.

Published by

Charles University in Prague, Center for Economic Research and Graduate Education (CERGE) and

Economics Institute (EI), Academy of Sciences of the Czech Republic

CERGE-El, Politických vězñu 7, 11121 Prague 1, tel.: +420 224005 153, Czech Republic.

Printed by CERGE-EI, Prague

Subscription: CERGE-El homepage: http://www.cerge-ei.cz

Editors: Directors of CERGE and EI

Managing editors: Deputy Directors for Research of CERGE and EI

ISSN 1211-3298

ISBN 80-7343-051-7 (Univerzita Karlova v Praze, CERGE)

ISBN 80-7344-040-7 (Národohospodářský ústav AV ČR, Praha) 
CERGE-EI

P.O.BOX 882

Politických vězňů 7

11121 Praha 1

Czech Republic http://www.cerge-ei.cz 